\title{
Henrique da Silva Fontes e a criação da Universidade Federal de Santa Catarina
}

\author{
Rogerio F. Guerral \\ Universidade Federal de Santa Catarina
}

\section{As universidades medievais}

\begin{abstract}
A s universidades surgiram na Europa medieval e eram corporações mantidas pela Igreja Católica ou por monarcas esclarecidos. Elas eram compostas por escolas isoladas e atraiam alunos e mestres da Inglaterra, Alemanha e França, por exemplo; a convivência intensa facilitava o florescimento de traços culturais comuns. As diferenças na comunicação eram contornadas com o uso de uma lingua franca, o Latim. Essas instituições eram conhecidas como universidades, não em razão de sua estrutura organizacional, mas porque eram lá que as essências ou os universais eram examinados. As datas e as circunstâncias como elas surgiram suscitam incertezas, mas conta-se que a primeira universidade surgiu em Bolonha (c.904), envolvendo os estados-nações que mais tarde iriam compor a moderna Itália. Na França, a Universidade de Paris (c.1208) envolvia as escolas de Notre-Dame, Sainte Geneviève e Saint Victor; ela foi estabelecida a partir da bula papal de Inocêncio II e contou com professores conhecidos, como São Tomás de Aquino (1225-74), Doctor Angelicus, e São Boaventura (c.1221-74), Doctor Seraphicus.

Outras instituições importantes são Oxford University (1167) e Cambridge University (1209). A primeira posui 36 colleges, sendo a University College (1249) o mais antigo deles - Lady Margaret Hall, college feminino, só surgiu muito tempo depois (1878). Era grande a mobilidade dos professores e alunos, pois a insatisfação promoveu a migração destes para o Reino Unido; eles foram incorporados na Oxford University. Por seu turno, os estudantes insatisfeitos de Oxford migraram em massa e deram origem a Cambridge University, a segunda instituição mais antiga do Reino Unido ${ }^{2}$.

O conceito moderno induz a crer que as universidades eram instituições sólidas, contavam com recursos regulares e os membros da comunidade gozavam de liberdade acadêmica, mas a verdade era o oposto. Essas instituições sobreviviam graças aos interesses das autoridades religiosas e aos privilégios

${ }^{1}$ Professor-Titular e editor da Revista de Ciências Humanas. Universidade Federal de Santa Catarina, Departamento de Psicologia, Campus Universitário, Florianópolis, SC, 88040-900 (rfguerra@cfh.ufsc.br).

2 Oxford English reference dictionary. Oxford: Oxford University Press, 1995

The history today companion to British history. Londres: Collins \& Brown, 1995.
\end{abstract}




\section{UMANAS}

concedidos pelos monarcas - estudantes e professores eram considerados membros da Igreja Católica e, portanto, somente eram presos e julgados por um tribunal eclesiástico. Teses que supostamente afrontavam as Sagradas Escrituras eram examinadas com atenção e, em casos especiais, seus defensores enfrentavam a ira desses tribunais; foi o que ocorreu com Galileu Galilei (15641642), da Universidade de Pisa, que postulou teses contrárias à harmonia das esferas celestes e acerca da posição privilegiada da Terra em relação aos demais corpos estelares; ele foi condenado à prisão perpétua, mas terminou os dias confinado na própria casa. Outros personagens da vida universitária encontraram a morte nos tribunais da Inquisição, como John Huss (c.1372-1415), pregador e reitor da Universidade de Praga, e Giordano Bruno (1548-1600), filósofo italiano e defensor da teoria de um número infindável de sóis. Ambos pereceram nas fogueiras armadas pelos tribunais do Santo Ofício.

O conceito que se tinha acerca das universidades, no período medieval, pouco tem correspondência com o conceito moderno de um instituição equivalente. A relação professor-aluno era algo bastante pessoal, a liberdade acadêmica era algo desconhecido e a publicação de idéias passava por um exame minucioso, de acordo com os interesses da Igreja Católica e de seus patronos. Os títulos acadêmicos praticamente inexistiam, os exames eram direcionados ao Trivium (Gramática, Lógica e Retórica) e Quadrivium (Música, Aritmética, Geometria e Astronomia). A primeira instituição moderna de ensino superior foi a Universidade de Halle (1694), na Alemanha. Alguns países das Américas (e.g., República Dominicana, Peru e Equador) já possuiam instituições de ensino superior, mas não eram equivalentes ao modelo moderno que temos de uma universidade. Os EUA contavam com a Harvard University (1636), mas ela se assemelhava mais a uma instituição de ensino secundário - a média etária dos estudantes era 16 anos - e não havia envolvimento com a pesquisa científica.

As investigações científicas passavam ao largo das universidades, o ensino era deficiente e as instituições quase desapareceram na Europa medieval (PERKIN, 2007). Os professores não tinham salário fixo e sobreviviam das remunerações pagas pelos alunos; a "clientela" também era pobre, pois as famílias mais abastadas contratavam tutores para a educação dos filhos, a qual se restringia ao ensino de etiquetas, habilidades musicais e poéticas (as moças) ou diplomacia, esgrima, equitação e artes marciais (os rapazes). As atuais universidades européias são conhecidas por suas catedrais de estilo gótico, torres imponentes e jardins bem cuidados, o que dá a impressão que elas usufruiam prestígio e não passavam por dificuldades orçamentárias. A beleza é enganosa, pois tais construções pertenciam às igrejas ou eram castelos emprestados pelos nobres. A situação real era calamitosa e muitas universidades desapareceram com o tempo. 


\section{Henrique da Silva Fontes e a criação da Universidade Federal de Santa Catarina}

Os alunos enfrentavam sérios problemas para aquisição de livros, moradia e alimentação (VERGER, 1990; BYRD, 2001). Alguns mestres alugavam quartos aos alunos pobres em troca de alguns serviços; os livros eram alugados, os professores eram pagos diretamente pelos alunos e era comum o compartilhamento das despesas. No século 13, surge uma novidade: a criação dos colleges, instituições mantidas por dignatários para abrigar estudantes pobres. Eles eram segregados nesses albergues, usavam uniformes e seguiam um código restritivo de conduta - as bebedeiras e arruaças eram comuns em Oxford e Cambridge. Os estudantes preenchiam as noites e os momentos de clausura com debates e discussões sobre as idéias dos mestres, as quais surgiam espontaneamente e atraiam intelectuais não-pertencentes à comunidade. Os colleges ganharam fama e se multiplicaram na Europa medieval.

As mulheres não tinham acesso às universidades, pois era inimaginável turmas mistas de rapazes e moças, tampouco se encontrava justificativas para a educação feminina. Em Cambridge, os colleges para as moças surgiram em 1869 , mas até 1948 elas não tinham acesso aos títulos universitários. Na Europa, pouquíssimas mulheres obtinham os títulos, mas a porcentagem se elevou de 14 para $22 \%$, nos anos 1920 e 1940 , respectivamente - a situação era um pouco melhor nos EUA, pois a porcentagem das mulheres, no ano 1940, era cerca de 30\% (ver PERKIN, 2007). As mulheres enfrentavam sérias dificuldades para ingressarem nas universidades, mas a situação dos negros era ainda pior, pois a segregação racial lhes fechava as portas até os anos 1970. No Reino Unido, algumas procedimentos modernizantes foram a eliminação dos requisitos religiosos (University Test Acts, 1871) e a instalação quase simultânea do Cavendish Laboratory, o qual inaugurou as experimentações científicas na Cambridge University.

A vida dos professores não era fácil, pois os rendimentos eram irregulares e o montante nada tinha de atraente. É difícil um cálculo preciso, mas estima-se que os professores geralmente tinha uma remuneração parecida com a de um operário comum - cerca de 30 a 50\% dos professores de Pávia recebiam menos que 50 florins, montante pago aos operários não-qualificados. Eles exerciam atividades complementares (copistas ou preceptores), tinham alguns privilégios fiscais e buscavam os honorários dos alunos para melhorar o padrão de medíocre de vida (VERGER, 1990).

\section{O ensino superior no Brasil}

A história do ensino superior no Brasil é recente e cheia de percalços: as instituições surgiram tardiamente e as autoridades portuguesas impediram ou dificultaram a instalação de escolas e publicação de livros e jornais. 


\section{UMANASta de Ciencias}

Mesmo após as proclamações da independência (1822) e da república (1889) não ocorreram melhorias substanciais nas instituições de ensino superior, tanto no que diz respeito ao aumento numérico, quanto o aperfeiçoamento das poucas instituições existentes; o que ocorreu foi o desaparecimento de algumas instituições e o aviltamente do status social dos educadores. A trágica situação merece ser bem descrita, pois o Brasil contava com homens notáveis que se destacaram como cultores da ciência, entre os quais José Bonifácio (1763-1838), mineralogista competente e ex-professor da Universidade de Coimbra, conhecido como o "Patriarca da Independência", e o imperador D. Pedro II (1825-91), o qual mantinha bom relacionamento com vários cientistas da França e Alemanha.

A instalação da família real no Brasil (1808) e a abertura dos portos às nações amigas permitiram, respectivamente, o surgimento de importantes instituições acadêmicas e a vinda de vários naturalistas às nossas terras. Eles eram atraídos pelas recursos naturais, mas o encantamento exploratório não se traduziu no fortalecimento das nossas instituições acadêmicas. A Europa estava passando por profundas mudanças, foram criadas instituições universitárias e as mentes mais esclarecidas julgavam que as investigações científicas eram o caminho mais seguro para o progresso da humanidade. Algo ainda mais intenso ocorria na França e Inglaterra, mas os ventos civilizatórios desviaram de rumo e até houve quem fosse contrário à criação de uma universidade no Brasil.

As famílias de alto padrão aquisitivo enxergavam certa vantagem na manutenção desse atraso intelectual, pois preservavam certos privilégios e tinham os recusos necessários para enviar os filhos à Portugal para terem algum lustro civilizatório. Até a metade do século 18, os professores da Universidade de Coimbra não tinham conhecimentos das idéias de Descartes, Newton e Leibniz; os alunos da Academia Real de Marinha e os candidatos à carta de oficiais engenheiros sequer tinham aulas sobre cálculo diferencial integral (CASTRO, 1950).

O sonho de instalação de uma verdadeira universidade no Brasil é antigo e o mais capacitado a realizar esse sonho era José Bonifácio. Ele pertenceu a várias sociedades científicas da Europa e teve a honra de inaugurar, na Universidade de Coimbra, a cátedra de metalurgia (1801). Por ocasião do retorno ao Brasil (1819), conta-se que D. João VI lhe ofereceu a missão de criar uma universidade, mas as agitações políticas terminam por lhe dar novos rumos na vida. Entre 1822 e 1889, o sonho de instalação de uma universidade no Brasil sofreu sérios revezes: conta-se que surgiram 42 projetos, entre os quais os de José Bonifácio e Ruy Barbosa, mas foram sistematicamente recusados pelo Governo e parlamento - nos Anais do Congresso (1882), que ocorreu sob a presidência do Conde D'Eu, um conselheiro atacou violentamente a proposta, classificando as universidades de coisas obsoletas (MENDONÇA, 2000). 


\section{Henrique da Silva Fontes e a criação da Universidade Federal de Santa Catarina}

Na última Fala do Trono (3 de Maio de 1889), o imperador D. Pedro II apresentou a proposta de criação de duas universidades, uma no Norte, outra no Sul do país (DEAZEVEDO, 1950; FÁVERO, 2006). A proposta foi anunciada no mesmo ano da Proclamação da República (1889) e não teve maiores conseqüências.

Algumas escolas e instituições isoladas deram notáveis contribuições aos avanços científicos, como a Faculdade de Medicina da Bahia (1808) e a Escola de Minas de Ouro Preto (1876). A primeira foi o berço da Escola Tropicalista Bahiana e da medicina legal; foi lá que surgiu o primeiro periódico científico (Gazeta Médica da Bahia, 1866), iniciativa de três ilustres estrangeiros: John Ligertwood Paterson (1820-83, escocês), Otto Edward Henry Wucherer (182073, português e de ascendência alemã) e João Francisco da Silva Lima (18261910, português). A Escola de Minas de Ouro Preto inovou no ensino de engenharia, graças ao dinamismo de Henri Gorceix (1842-1919), mineralogista francês contratado pelo governo brasileiro para organizar a nova instituição. Os alunos contavam com bolsas de estudo, praticava-se a pesquisa experimental e muitos professores eram estrangeiros e tinham dedicação exclusiva (LEONARDOS, 1950; DE AZEVEDO, 1950).

A criação do Instituto Soroterápico (1901) foi outra experiência inovadora, embora os seus propósitos iniciais não fossem o ensino ou a pesquisa. Ele foi instalado no Rio de Janeiro para produzir soro antipestoso e combater a febre amarela que atormentava os cariocas (1899), mas o sucesso ampliou suas atividades e deu renome internacional às ciências biomédicas do Brasil. $\mathrm{O}$ centro de pesquisa edita um antigo e tradicional periódico (Memórias do Instituto Oswaldo Cruz) e o nome atual (Instituto Oswaldo Cruz) é uma adequada homenagem ao seu idealizador. Em 1918, o grupo de sanitaristas enfrentou sérias dificuldades, pois as autoridades não lhes deram o apoio necessário e a população se rebelou veementemente contra a vacinação obrigatória (LENT, 1943; DE AZEVEDO, 1950; MARTINS, 1950). Os maiores obstáculos à sobrevivência do Instituto Oswaldo Cruz se encontravam na própria Academia Nacional de Medicina, pois alguns de seus membros duvidavam das descoberta dos pesquisadores de Manguinhos e os classificavam como "bisonhos descrevedores de espécies novas" (FONSECA FILHO, 1974).

\section{Momentos da vida universitária}

As datas de criação das universidades suscitam controvérsias acerca da real antiguidade. Algumas registros apontam que a Universidade Federal do Paraná é a mais antiga, mas ela foi uma aglutinação de escolas isoladas já existentes; a atividade científica não era institucionalizada e tampouco estava relacionada ao ensino, além do que ela teve vida descontinuada - foi criada em 1912, 


\section{HUMANAS}

encerrou as atividades na década seguinte, por imposição do Governo Federal, e renasce muitos anos depois (4 de Dezembro de 1950); o "ressuscitamento" ocorre cerca de trinta anos depois do encerramento das atividades e, portanto, é razoável concluir que sejam instituições distintas.

Fernando de Azevedo (1950) apontou que a primeira universidade brasileira foi a do Rio de Janeiro (Decreto 14.343, 7 de Setembro de 1920), mas ela não passou de uma agregação de três instituições então existentes (Faculdade de Direito, Faculdade de Medicina e Escola Politécnica), tampouco ocasionou quaisquer modificações na estrutura e nos métodos de ensino. Foi algo que surgiu apenas nos documentos oficiais. Por outro lado, em termos comparativos, alguns países das Américas já se encontravam bastante avançados no ensino superior, como a República Dominicana (Universidad Autónoma de Santo Domingo, 1538), o Peru (Universidad Nacional Mayor de San Marcos, 1551) e Argentina (Universidad Nacional de Córdoba, 1610); a influência dos missionários católicos parece ter sido positiva, pois as universidades protestantes dos EUA (Harvard University, 1636) e do Canadá (University of New Brunswick, 1785 ) vieram mais tarde.

Essas datas não têm muita significância, caso examinemos o real significado da palavra "universidade". Os registros apontam a instalação dessas instituições nos primórdios da colonização hispânica (meados do século 16), mas pouco informam sobre o modo de funcionamento. É razoável supor que o Brasil não se encontrava tão atrasado como imaginamos, pois os antigos colégios jesuítas poderiam ser equivalentes às universidades instaladas no Peru e na República Dominicana. Não obstante isso, alguns registros ainda indicam que os missionários jesuítas pretendiam instalar uma universidade no Brasil (1583), mas o projeto foi abortado pela expulsão dos inacianos de Portugal e de sua colônia, o Brasil. Os inconfidentes mineiros também acalentavam sonhos parecidos, mas as torturas e os enforcamentos não permitiram que as idéias prosperassem (MARTINS, 1950; MENDONÇA, 2000; FÁVERO, 2006).

O Brasil sempre esteve numa posição desvantajosa no ensino superior, mas, interessantemente, a Encyclopcedia Britannica não descreve a situação de modo tão negativo. Ela informa que as três instituições universitárias mais antigas são a Universidade Federal da Bahia (1808), a Universidade Federal do Paraná (1912) e a Universidade Federal do Rio de Janeiro (1920) - a USP foi a $7^{\mathrm{a}}$ instituição universitária a ser instalada no país, de acordo com seus registros ${ }^{3}$. A suposta data de criação da Universidade Federal da Bahia (1808) é uma referência à criação da Faculdade de Medicina, criada por D. João VI por ocasião da transferência da corte para o Brasil - ele estava em fuga das tropas napoleônicas e, percebendo que iria despender um bom tempo no país,

\footnotetext{
${ }^{3}$ The new Encyclopcedia Britannica. Micropædia, volume 12. Chicago: Encyclopædia Britannica,
} Inc., 1986. 


\section{Henrique da Silva Fontes e a criação da Universidade Federal de Santa Catarina}

resolveu atenuar a proibição de instalar instituições de ensino ou a publicação de jornais e livros no Brasil. Outra imprecisão contida no verbete da Encyclopcedia Britannica é o registro numérico de livros das universidades brasileiras: ele informa que a Universidade Federal de Pernambuco conta com acervo bibliográfico de 418 mil volumes, dez vezes superior ao acervo da USP (40 mil volumes).

\section{Modernidade, desenvolvimento e progresso}

A inaguração do ensino superior permitiu a inserção do país no rol das nações civilizadas, mas a luta foi árdua. Os pioneiros não contavam com as comodidades da vida moderna e estavam inaugurando novos procedimentos. Outro problema grave e pouco examinado era a estrutura administrativa das antigas unidades de ensino. O sistema era verticalizado e se assentava na autoridade do professor catedrático; o título é mais ou menos equivalente ao professeur das faculdades européias ou ao professor-titular das atuais universidades. Valorizava-se mais os gestos formais ou o vocabulário estranho que a competência acadêmica propriamente dita. $\mathrm{O}$ artificialismo e a loquacidade estéril, mas sedutora, até inspirou as obras de Machado de Assis (Teoria do medaIhão, 1881) e Eça de Queirós (Correspondência de Fradique Mendes, 1900). O sistema acadêmico facilitava a vida dos professores-barnabés, eles faziam de tudo para não perderem suas cátedras, para prejuízo da boa funcionalidade das instituições e dos avanços do conhecimento.

A burocracia governamental dificultava as inovações em todos os setores, a ponto de ocasionar uma grave perturbação mental no Major Quaresma, personagem da obra de Lima Barreto (Triste fim de Policarpo Quaresma, 1911) - ele apenas desejava implantar uma "lavoura científica" em sua propriedade, mas esbarrou na indiferença governamental e nos entraves burocráticos das repartições públicas. O escritor Antero de Quental (1842-91) apontou o espírito anti-científico como o responsável pela decadência de Portugal e, conseqüentemente, atraso de sua colônia:

A uma geração de filósofos, de sábios e de artistas, sucede (na Península Ibérica) a tribo invulgar dos eruditos em crítica, dos acadêmicos, dos iniciadores... Nos dois últimos séculos não produziu a Peninsula um único homem superior que se se possa pôr ao lado dos grandes criadores da ciência moderna; não saiu da Península uma só das grandes descobertas intelectuais que são a maior honra do espírito moderno... A Europa culta engrandeceu-se, 


\section{HUMANAS}

nobilitou-se, subiu sobretudo pela ciência; foi sobretudo pela falta de ciência que nós descemos, que nos degradamos, que nos anulamos. A alma morrera dentro de nós completamente ${ }^{4}$.

O país era governado por sofistas e beletristas, sobravam as paixões literárias e faltavam os elementos essenciais para a construção de uma nação civilizada. Esse espírito anti-científico e o horror às coisas práticas promoviam o surgimento de um falso humanismo e o eruditismo ornamental. O fenômeno foi denunciado por Ruy Barbosa (1849-1923), renomado jurista que defendia amplas reformas no sistema educacional. Essa era a condição para os avanços civilizatórios, conforme descreve um de seus discursos:

Somos um povo de sophistas e rethoricos nutrido
de palavras, victima do seu mentido prestígio, e
não reparamos em que essa perversão, origem de
todas as calamidades, é obra da nossa educação,
na escola, na família, no collegio, nas faculdades. O
nosso ensino reduz-nos ao culto mechanico da phra-
se: por ella nos advem feitas e recebemos, inverifi-
cadas, as opiniões que adoptamos: por ella desa-
costumamos a mente de toda acção propria; por
ella entranhamos em nós o vezo de não discernir
absolutamente a realidade

Nas primeiras décadas do século 20, o Brasil contava com algumas escolas de ensino superior e existia o projeto de criação de uma universidade, mas o desejo não saiu do papel (SCHWARTZMAN, 1980). O cenário causava constrangimentos, mas sofre uma mudança com a criação da primeira e genuína instituição universitária, a Universidade de São Paulo (1934). Houve aglutinação de algumas faculdades isoladas, mas a experiência foi inovadora em razão de quatro fatores: as unidades foram reunidas na Cidade Universitária, diversos intelectuais e cientistas estrangeiros foram contratados para compor seus quadros, implantou-se o sistema de dedicação exclusiva, com salários adequados, e, mais importante, surgiu a Faculdade de Filosofia, Ciências e Letras. O estudo das "essências e dos universais" tinha lugar garantido na USP. A iniciativa surgiu no governo de Júlio de Mesquita Filho (1892-1969) e Armando Salles de Oliveira (1887-1945), tendo como referência as modernas universidades européias. A USP buscou a perfeita integração entre as investigações científicas e o ensino, principalmente no que diz respeito às ciências naturais, ganhou renome internacional e se destacou das universidades mais antigas da América do Sul.

\footnotetext{
${ }^{4}$ Causas da decadência dos povos peninsulares nos últimos três séculos. Lisboa: Typographia Comercial, 1871.

5 Orações do apóstolo. Rio de Janeiro: Edição da Língua Portuguesa, 1923.
} 


\section{Henrique da Silva Fontes e a criação da Universidade Federal de Santa Catarina}

Outra experiência inovadora surgiu no Rio de Janeiro, antiga capital do país. Ela ocorreu na administração do prefeito Pedro Ernesto (1931-36) e foi idealizada por Anisio Teixeira (1900-71). A Universidade do Distrito Federal (UDF) foi criada em 1935 e tinha propósitos ainda mais inovadores que os da USP; ela contemplava os anseios dos intelectuais de duas agremiações importantes (Academia Brasileira de Ciências e Associação Brasileira de Educação). A UDF era o local adequado para as "atividades científicas e produção cultural desinteressada". Os objetivos e os modos de atuação foram especificados, valorizava-se a liberdade acadêmica e os dirigentes buscaram na Europa os intelectuais necessários para compor suas unidades. Não obstante os elevados ideais, a UDF teve menos que quatro anos de vida, pois o Decreto 1063 (20 de Janeiro de 1939) impõe a sua extinção - os cursos são transferidos para a Universidade do Brasil, atual UFRJ. Gustavo Capanema (190085), ministro da Ecucação, manifestou-se contrário ao projeto e, alegando a manutenção da ordem e da disciplina, envia ao presidente Getulio Vargas os motivos que, no seu entendimento, determinam o encerramento das atividades da UDF (ver FÁVERO, 2006; VASCONCELOS, 2007). O malogro da experiência de Anisio Teixeira é mais um capítulo da tumultuada história das universidades brasileiras.

O conceito moderno de universidade tem como referência o ensino (graduação e pós-graduação) e as investigações científicas. O objetivo é a formação de uma elite intelectual que impulsione o desenvolvimento científico e tecnológico. A USP surgiu num momento de grande ebulição intelectual, levando em conta a Semana de Arte Moderna (1922) e a Revolução Constitucionalista (1932), episódios de forte significado nacionalista. A Reforma Educacional Francisco Campos (1931), que ocorreu durante o governo de Getúlio Vargas (193045), propõe a ênfase humanística na formação acadêmica e estabelece normas para a criação dos programas de doutoramento. É nesse contexto que surgem a Universidade de São Paulo (1934) e sua inovadora Faculdade de Filosofia, Ciências e Letras.

Os idealizadores da USP entendiam que as universidades formavam uma elite intelectual, produziam os necessários avanços do conhecimento e impulsionavam o país rumo à modernidade. Entretanto, os sonhos só se contretizam com recursos orçamentários e apoio às lideranças acadêmicas e, portanto, as ações coordenadas deram origem a duas agências governamentais: o Conselho Nacional de Pesquisas (o nome foi mudado para Conselho Nacional de Desenvolvimento Científico e Tecnológico, mas preservou-se a abreviatura $\mathrm{CNPq}$ ) e a Coordenadoria de Aperfeiçoamento do Pessoal de Ensino Superior (CAPES). As duas agências foram criadas em 1951 e tinham propósitos complementares: a primeira cuidava do fomento às investigações científicas, a outra cuidava da formação de professores e pesquisadores (SCHWARTZMAN, 1980; CASTRO, 1985). 


\section{UMANAS}

É importante relembrar que no governo de Juscelino Kubitschek de Oliveira (1956-61) foram promulgados alguns decretos que permitiram a ampliação numérica das universidades federais - 1960 foi o ano de criação da Universidade Federal de Santa Catarina.

\section{Instituto Polytechnico de Santa Catarina}

O ensino superior catarinense foi inaugurado com o início das atividades do Instituto Polytechnico (13 de Março de 1917); a instituição teve vida curta e tumultuada, mas os eventos merecem registro. Em 2 de Outubro de 1909, a Lei Estadual 839 previa a instalação de uma instituição de ensino superior em Santa Catarina; a idéia inicial focalizava os cursos de Farmácia, Obstetrícia e Odontologia. O projeto não saiu do papel, mas o desejo da intelectualidade catarinense foi materializado com a fundação do Instituto Polytechnico, fato que ocorreu a partir das reuniões de médicos, farmacêuticos, dentistas, bacharéis em Direito. O projeto acompanhava a tendência dos estados mais desenvolvidos e foi liderado por José Arthur Boiteux (1865-1934); os objetivos iniciais foram redefinidos, pois a instituição passou a ofertar os cursos de Agrimensura, Comércio, Farmácia, Odontologia e Pilotagem (transporte naval).

A novidade foi noticiada pelos jornais $O$ Estado e A Época (14 de Fevereiro de 1917). A primeira diretoria (1917-22) foi composta por Augusto Fausto de Souza (Diretor), Joaquim David Ferreira Lima (Vice-Diretor), José Arthur Boiteux (Secretário), Achylles Wedekin dos Santos (Sub-Secretário) e Henrique Rupp Jr. (Tesoureiro). O Instituto Polytechnico funcionou precariamente e a sua curta existência foi resultante das dificuldades administrativas e falta de recursos orçamentários. Em outras palavras: não existia massa crítica que proporcionasse a busca por seus cursos e tampouco os professores tinham envolvimento integral com o ensino - o salário era pouco atraente (ver: ROSA \& MADEIRA, 1978; BLASS \& GUERRA, 2007).

Os problemas se agravaram em razão da inexistência de uma legislação favorável à autonomia dessas instituições ou de mecanismos governamentais de apoio ao ensino e à pesquisa. Os jovens das famílias abastadas não se interessavam pelos "cursos práticos" e buscavam no Rio de Janeiro ou em outras capitais os cursos de Direito ou de Medicina, os quais a simples matrícula elevava o status social dos futuros doutores. Em 1932, o Diretor Heráclito Carneiro Ribeiro renuncia e a instituição sofre intervenção do Governo Estadual (Dezembro de 1932 a Agosto de 1933). As irregularidades detectadas pelo Ministério da Educação e Saúde Pública dificultam ainda mais o funcionamento do Instituto Polytechnico, de modo que em 1935 ele encerra as atividades - 


\title{
Henrique da Silva Fontes e a criação da Universidade Federal de Santa Catarina
}

a última turma do curso de Odontologia havia se formado em 1932. Alguns detalhes do funcionamento do Instituto Polytechnico mereceram os comentários de Victor Peluso, ex-aluno daquela instituição e antigo professor da UFSC:

\begin{abstract}
O fundador do estabelecimento foi o Desembargador José Arthur Boiteux. Havia, na própria escola, curso de preparatório, que permitia os exames parcelados de nível secundário, e o Curso anexo, que aperfeiçoava os conhecimentos em matemática, para os candidatos aos cursos de Agrimensura e Engenheiro-Géografo. Além desses dois cursos havia o de Farmácia, Odontologia e Comércio. Os professores eram profissionais residentes na cidade, como o farmacêutico Henrique Brüggemann, o médico Dr. Carlos Correa, os engenheiros Dr. Celso Salles, Dr. Haroldo Pederneiras, Dr. Oscar Ramos e outros mais (PELUSO, 1986; p. 93).
\end{abstract}

O Instituto Polytechnico ficou entregue à própria sorte e outros fatores contribuiram para o insucesso dos planos de José Arthur Boiteux e de seus colaboradores. Florianópolis se encontrava distante dos grandes centros urbanos (Rio de Janeiro e São Paulo) e não tinha auto-suficiência econômica e cultural. Até 1950, o sistema de transporte era bastante precário e as pessoas levavam alguns dias para chegar ao Rio de Janeiro, a capital do país; o modo mais rápido de transmissão de notícias era por cabograma ou telegrama. Tais dificuldades explicam a curta existência do Instituto Polytechnico, mas também valorizam as ações dos pioneiros do ensino superior catarinense.

O funcionamento era precário, as instituições não contavam com o apoio governamental e sobreviviam graças aos esforços de seus dirigentes. A importância dessas unidades era inquestionável, pois elas contribuiam de algum modo para o desenvolvimento da mentalidade científica. A Escola Politécnica do Rio de Janeiro era conhecida por seus cursos de matemática e ciências físicas; eles contavam com alunos regulares, mas o Governo Provisório (1890) resolveu suprimí-los. Os cursos científicos sobreviveram por mais alguns anos, graças aos apelos dos lentes, mas a própria Congregação os extingue (1896). Tal como ocorreu em Santa Catarina, essas unidades desempenharam importantes funções, pois não existia universidade e eram nessas unidades que os alunos tinham alguma formação em matemática e ciências naturais. Paulo Freitas (1901), lente da cadeira de Estradas de Ferro e Rodagem, expôs com clareza o significado do encerramentos desses cursos: 


\section{HUMANAS}

Uma vez que o Brazil não possue ainda uma Universidade, não deve a Escola Polytechnica Federal abandonar a idéia de manter os seus antigos cursos científicos. Ella é a única que está nas condições de realizar esse desideratum, em vista dos elementos tradicionais de que dispõe. Assim o pensamos, ainda que tivessemos concorrido para a reforma de 1896, onde entretanto a solução dependeu de votação; pelo que não deixaremos de lembar que foi sempre nosso pensamento a fundação de Universidade no Brazil e o exaramos na Memória que redigimos, e figura no livro do Congresso de Instrucção do Rio de Janeiro em 1882 (In: CASTRO, 1950; p. 77).

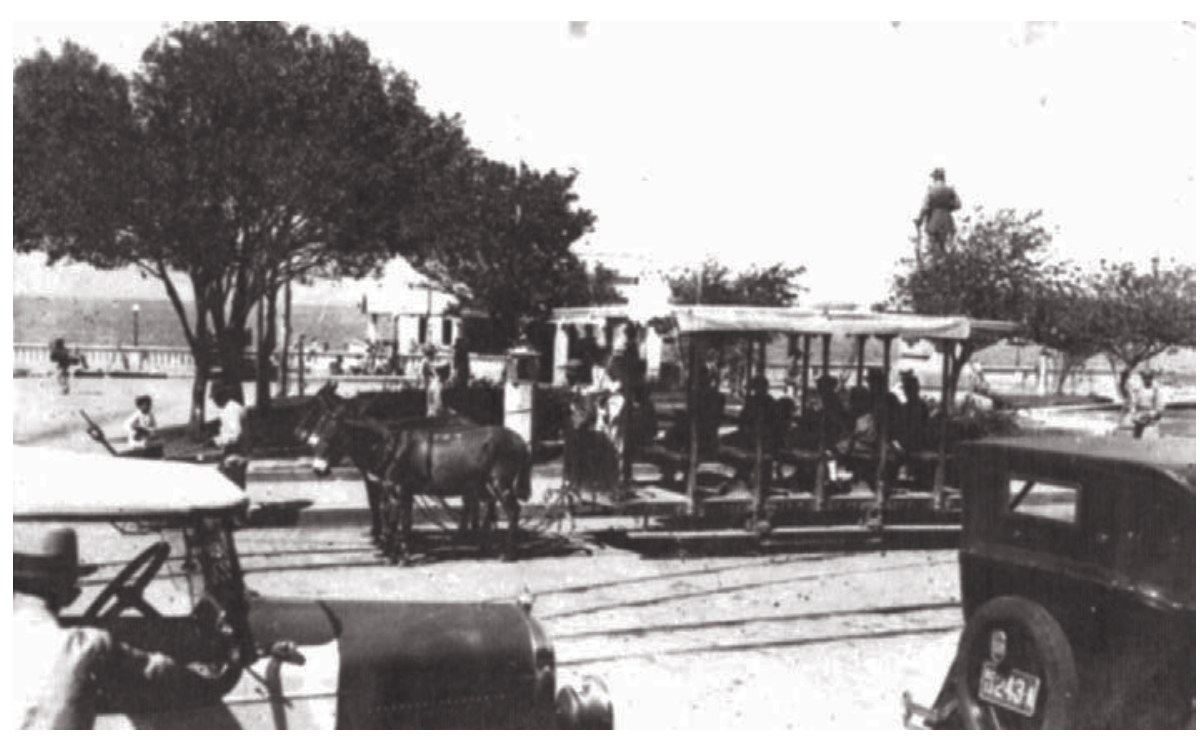

Figura 1

A beleza e a vida tranqüila em Florianópolis nos anos 1950. Os automóveis eram quase inexistentes e o meio de transporte mais comum era o bondinho-de-burro.

O que ocorreu com encerramentos das atividades do Instituto Polytechnico foi algo parecido ao que ocorre rotineiramente no mundo das experimentações científicas: às vezes, o fracasso é um evento auspicioso e cheio de ensinamentos. Com efeito, os erros e desacertos tiveram certos efeitos positivos, pois eles indicaram o que não deveria ser feito, ou o caminho mais seguro a ser seguido, de modo que, simultaneamente à formação da última turma do curso de Odontologia, do Instituto Polytechnico, surge a Faculdade de Direito (instalada em 1932, oficializada por um decreto do Governo Estadual em 1935). 
Henrique da Silva Fontes e a criação da Universidade Federal de Santa Catarina

Parece que ventos favoráveis começam a soprar, pois outras instituições são instaladas a seguir: Faculdade de Ciências Econômicas (1943), Faculdades de Farmácia e Odontologia (1947) e Faculdade Catarinense de Filosofia (1951). Visando garantir a sobrevivência do Instituto Polytechnico, Boiteux ainda imaginou que ele pudesse ser aglutinado à recém-criada Faculdade de Direito, mas o sonho não prosperou - ele estava bastante adoentado e morreu logo em seguida (8 de Janeiro de 1934). Caso os planos fossem bem sucedidos, os catarinenses estariam bastante avançados no que diz respeito à instalação de uma verdadeira universidade.

\section{Faculdade de Direito}

O Instituto Polytechnico e a Faculdade de Direito surgiram a partir das iniciativas de Boiteux, sendo que a última foi administrada por Henrique da Silva Fontes, colaborador próximo e que compartilhava as mesmas idéias e os mesmos ideais. Não se sabe exatamente o que Boiteux tinha em mente quando apresentou a proposta de aglutinação das duas instituições, mas parece que ele desejava fortalecer o ensino superior a partir da criação de uma instituição mais adequada aos desejos dos filhos das famílias mais abastadas e cujo sucesso pudesse influenciar positivamente a saúde do moribundo Instituto Polytechnico. As idéias não prosperaram, mas a instituição em fase terminal ainda conseguiu expelir boas sementes. Com efeito, durante uma reunião da Congregação do Instituto Polytechnico (21 de Dezembro de 1931), Boiteux apresenta a proposta de criação da nova instituição e, ato contínuo, uma comissão é constituída para dar prosseguimento aos planos. Ela foi constituída pelo próprio Boiteux, mais os professores Américo da Silveira Nunes (Efetivo) e Henrique da Silva Fontes (Interino).

Um convite circular (2 de Fevereiro de 1932) foi enviado aos bacharéis em Direito da capital, notificando-os dos propósitos da comissão e da reunião que logo seria realizada (11 de Fevereiro). O convite foi direcionado a 37 pessoas e 15 delas compareceram à histórica reunião: Américo da Silveira Nunes, Heráclito Carneiro Ribeiro, José Arthur Boiteux, Salvio de Sá Gonzaga e Urbano Müller Salles, os juízes Adalberto Belisário Ramos, Alfredo von Trompowsky, Henrique da Silva Fontes e Zulmiro Soncini, os bacharéis Afonso Guilhermino Wanderley Júnior, Edmundo Accácio Moreira, Euclides Queirós de Mesquita, Heitor Salomé Pereira, Neri Kurtz e Othon da Gama Lobo D’Eça; dois bacharéis não compareceram, mas enviaram repreentantes: Fúlvio Coriolano Aducci e Pedro de Moura Ferro.

O número de participantes foi reduzido, levando em conta que três deles eram os próprios membros da comissão, mas foram tomadas decisões fundamentais para a criação da Faculdade de Direito. Ela foi inicialmente instalada na parte superior de um prédio situado no final da Rua Felipe Schmidt, 


\section{HUMANAS}

esquina com a Praça XV de Novembro. A instituição não contava com nenhum recurso próprio (a carta-convite foi enviada no dia 2 e ela nasce no dia 11 de Fevereiro), mas o aluguel foi garantido pelos professores-fundadores. Os esforços e a empolgação dos pioneiros prenunciavam que a iniciativa estava condenada ao sucesso, mas o estado emocional favorável não contaminou positivamente o Instituto Polytechnico e talvez tenha até contribuído para encurtar a sobrevida - constatado que ele era inviável, a empolgação dos pioneiros voltou-se para algo mais factível: a Faculdade de Direito.

Os comerciantes da região cederam mesas e armários, surgiu um livroouro para colher doações e Boiteux anunciava nos jornais os eventos ocorridos na novel instituição. A Faculdade de Direito estava funcionando de vento em popa e Boiteux foi alertado acerca da inexistência de uma placa indicando o funcionamento da instituição. Era uma despesa inesperada, mas o docentelivre Othon da Gama D'Eça se prontificou a bancar os custos e logo surgiu uma vistosa tabuleta anunciando "Faculdade de Direito". O episódio foi comemorado e deu origem a uma saborosa historieta.

Dois bares funcionavam na parte de baixo do prédio, onde os usuários faziam circular seus mexericos e galhofas - algumas maledicências ocasionavam o "sepultamento dos vivos, desenterro dos mortos", conforme relembra Fontes (1966). Apesar da vocação vetusta e dos formalismos que geralmente cercam tais instituições, alunos e professores compartilhavam esse ambiente, de modo que a Faculdade de Direito logo ganhou nova designação. Conta-se que um tabelião muito conhecido, já avançado na idade e com acentuada miopia, se deparara com a tabuleta e teve dificuldade em entender o que ela dizia, mas lobrigou que se tratava da "Alfaiataria do Didico". Ele ficou contente com a descoberta e exclamou: "Até que enfim o Didico encontrou casa para a sua alfaiataria!" Os galhofeiros não perderam oportunidade para inovar o vocabulário e perspegar um apelido à Faculdade de Direito: os futuros bacharéis eram pessoas "didicadas" ou eram alunos que se "didicavam" aos afazeres da "Alfaiataria do Didico".

Os registros apontam que as primeiras aulas foram ministradas por Pedro de Moura Ferro, catedrático de Introdução à Ciência do Direito, e Henrique da Silva Fontes, catedrático de Economia Política e Ciência das Finanças. Boiteux permaneceu pouco tempo à frente da Faculdade de Direito, pois ele tinha problemas de saúde e falece em 1934, mas Henrique Fontes assume os encargos e mantêm acesa a chama do ensino superior em Santa Catarina. A designação informal e as galhofas em torno da instituição caem no esquecimento, pois ela se transfere para um local mais amplo e distante dos bares da Rua Felipe Schmidt, a sua importância reduziu o espaço para galhofas e licenciosidades ou porque atualmente é difícil encontrar uma alfaiataria em funcionamento. 


\section{Henrique da Silva Fontes e a criação da Universidade Federal de Santa Catarina}

Os grandes personagens da vida cultural de Santa Catarina foram José Arthur Boiteux e Henrique da Silva Fontes. Não existem dúvidas acerca da importância de Boiteux para a instalação do ensino superior no estado, mas o seu espírito incansável ainda exerceu efeitos positivos na fundação da Academia Catarinense de Letras, do Instituto Histórico e Geográfico de Santa Catarina e de outras instituições. Ele era um tipo de liderança que não se intimidava com os obstáculos encontrados pela frente; o Instituto Polytechnico enfrentava sérias dificuldades diante do Ministério da Educação e o governo federal praticamente forçou o encerramento das atividades, invés de proporcionar auxílio aos dirigentes para correção dos problemas. Uma nova instituição de ensino superior foi criada e até houve a tentativa de aglutinar as duas instituições. Os planos não prosperaram e Henrique Fontes assume os encargos na Faculdade de Direito, daí surgindo o sonho de realização de uma obra mais complexa e mais abrangente: a instalação de uma universidade em Santa Catarina.

Henrique Fontes escreveu algumas notas biográficas sobre Arthur Boiteux, designando-o como o "Patriarca do Ensino Superior de Santa Catarina". O título é justificável, mas ele próprio foi outro construtor de instituições. Fontes herdou as responsabilidades de levar adiante a missão modernizante; ele assumiu a direção da Faculdade de Direito e, ato contínuo, começa a dar os primeiros passos em direção a um empreendimento mais complexo (i.e., a criação de uma universidade). A importância de seus feitos serão examinados a seguir.

\section{Faculdade Catarinense de Filosofia}

A Faculdade Catarinense de Filosofia (1951) tinha propósitos inovadores, como o envolvimento nas investigações científicas e a formação de uma intelligentsia catarinense. Fontes contratou os melhores professores, estimulou os talentos locais ("pratas da casa"), novos professores eram formados nos cursos de Licenciatura, os alunos adquiriam formação humanística e era na novel instituição que se praticava a "pesquisa pura". Era o modelo europeu que inspirara a criação da Faculdade de Filosofia Ciências e Letras da USP (1934) e que, por seu turno, fora adotado na Faculdade Catarinense de Filosofia e inspirara as demais instituições que vieram a seguir, federais ou estaduais. A unidade funcionava como estrutura de sustentação (alma mater) e era o requisito necessário para a abertura de uma universidade.

Qual seria a contribuição da novel instituição para os avanços do conhecimento? A maioria das universidades surgiu de aglutinação de unidades já existentes, as quais estavam mais voltadas para os cursos tecnológicos ou formação de médicos, inexistindo praticamente o investimento na pesquisa pura ou básica. 


\section{HUMANAS}

O ensino de engenharia, os estudos das leis e das práticas médicas já se encontravam razoavelmente bem estabelecidos, mas o Brasil ocupava uma posição bastante constrangedora em relação aos avanços científicos. $\mathrm{O}$ atraso seria corrigido a partir da criação de faculdades de Filosofia e Ciências, local adequado para a formação humanística e desenvolvimento das investigações científicas no campo das ciências naturais (e.g., geologia, química, astronomia e zoologia).

É interessante apontar o grau de parentesco das instituições: as reuniões do Instituto Polytechnico deram surgimento à Faculdade de Direito, da mesma forma que as discussões ocorridas nesta deram surgimento à Faculdade Catarinense de Filosofia; as instituições são aparentadas e foram resultantes do idealismo de Boiteux e Fontes, mais os pioneiros que se engajaram no projeto. O sucesso da Faculdade de Direito estimulou novos sonhos, como a idéia de instalação de um "Quarteirão Universitário" e a implantação da Faculdade Catarinense de Filosofia, alma mater e requisito necessário para a criação de uma verdadeira universidade. Fontes esteve à frente desses empreendimentos e contou com o apoio dos dirigentes do Colégio Catarinense para criar a nova instituição de ensino superior (CARMINATI, 2009). Ele tinha forte ligação com a Igreja Católica, principalmente com os padres jesuítas que comandavam a formação da elite intelectual catarinense.

Uma data importante é 6 de Setembro de 1951, ocasião em que Fontes, Urbano Müller Salles e Henrique Rupp Júnior enviam cartas às pessoas possivelmente interessadas na criação de uma nova instituição: "Tendo nós, juntamente com a Diretoria do Colégio Catarinense, verificado a possibilidade de imediata instalação de uma Faculdade de Filosofia, pois que o mesmo colégio, para início do funcionamento fornecerá as necessárias acomodações e o material preciso, vimos convidar V.Exa., caso queira pertencer aos respectivo corpo docente, para uma reunião em que se tratará da fundação da mesma faculdade e que se realizará no salão nobre da Faculdade de Direito, no dia 8 do corrente, às 20 horas..." (FONTES, 1966).

Os convites foram enviados às pessoas supostamente capacitadas a ministrar disciplinas na Faculdade Catarinense de Filosofia. A reunião ocorreu na Faculdade de Direito e a ocasião serviu para a escolha da primeira diretoria: Henrique da Silva Fontes (Diretor), Padre João Alfredo Rohr, SJ (Secretário) e Oswaldo Bulcão Vianna (Tesoureiro) (ver CARMINATI, 2009). Victor Antonio Peluso Jr., um dos nomes conhecidos da geografia brasileira, foi convidado a integrar o futuro corpo docente da instituição, mas esquivou-se da missão com o seguinte comentário:

A Faculdade Catarinense de Filosofia foi fundada quando estava na Secretaria da Agricultura. 


\title{
Henrique da Silva Fontes e a criação da Universidade Federal de Santa Catarina
}

\begin{abstract}
Quando houve a reunião das pessoas interessadas na criação da Faculdade, meu nome constava da relação dos futuros mestres. Declinei dessa honra, declarando que quando fosse instalado o curso de Geografia e História, eu seria candidato a frequentá-lo como aluno. Meu desejo era lecionar na Faculdade, mas desejava fazê-lo como diplomado em ciência que tanto me atraia. Não me foi possivel fazer parte da primeira turma de estudantes de Geografia e História. Quando me matriculei, veio a separação entre os dois cursos, e entrei no de Geografia (PELUSO, 1986; pp. 99-100).
\end{abstract}

Os encargos administrativos obrigavam Fontes a realizar muitas viagens e um triste, tristíssimo, episódio revela a gravidade da missão e os traços de sua personalidade. Em 8 de Maio de 1959, ele se encontrava no Rio de Janeiro para acompanhar de perto o processo de reconhecimento da Faculdade Catarinense de Filosofia, algo que ocorreu logo em seguida (Decreto 46.266, 26 de Junho de 1959). Foi a ocasião em que ele e o filho foram colhidos por uma inesperada notícia: o falecimento da filha Alba Maria da Luz Fontes Piazza, ocasionado por complicações do parto. Fontes foi informado que o sepultamento seria postergado até o seu retorno à Florianópolis, mas ele telegrafou para a família e informou que a sua presença não traria a filha de volta e que ele se encontrava numa missão que iria beneficiar enormemente Santa Catarina. Fontes pediu que o sepultamento fosse providenciado e disse: "Deus nos deu Alba, Deus nos tirou. Seja feita a sua vontade." Ele e o filho permaneceram alguns dias no Rio de Janeiro e foi providenciada uma missa de sétimo dia, a qual contou com a presença do Cônego Tomás Fontes e o conforto proporcionado pelos amigos catarinenses.

Fontes estava atento aos requisitos para a criação de uma universidade, no que diz respeito às necessidades de Santa Catarina e formação de uma elite intelectual. O local para abrigar as unidades começou com a idéia de implantação do "Quarteirão Universitário" e culminou com a Cidade Universitária (nome original). Os relatos autobiográficos informam que Fontes começou a pensar no projeto por volta de 1942, mas o passo decisivo foi a criação da Faculdade Catarinense de Filosofia, local favorável às investigações científicas e onde os alunos frequentariam os cursos de Licenciatura (formação de professores) e ganhariam algum lustro humanístico. Os propósitos da instituição e o desejo de criação de uma universidade foram explicitados no ato de sua criação ( 8 de Dezembro de de 1951, dia da Natividade de Nossa Senhora):

Esperamos que a Faculdade Catarinense, aliada às suas já acreditadas irmãs, possibilite, em breve, a ereção da Universidade de Santa Catarina, 


\section{HUMANAS}

que, se Deus quiser, prosperará dentro de uma $\mathrm{Ci}$ dade Universitária, espaçosa, tranqüila, hospitaleira e alegre (FONTES, 1966).

As universidades só ganham vida com as investigações científicas, mas os apressados podem indagar a si mesmos: qual é a ligação de uma Faculdade de Filosofia com as ciências naturais? O que é uma "ciência natural"? Para responder a tais indagações é necessário examinar os arcaísmos da vida acadêmica. Inicialmente, as universidades eram centros de debates e os assuntos religiosos predominavam, pois visavam o aprimoramento do Cristianismo e a delimitação entre a fé e a razão. A palavra Filosofia tinha amplo significado ou apenas indicava o "amor ao conhecimento" - o fator que promovia as explorações naturalísticas ("viagens filosóficas") e as experimentações científicas.

Alguns intelectuais percebiam que Portugal estava em decadência e que o processo seria interrompido a partir de amplas reformas no ensino, de modo a permitir o surgimento da mentalidade filosófica. Uma tentativa importante foi a reforma promovida pelo Marques de Pombal (1772), a qual modificou a estrutura de funcionamento da Universidade de Coimbra, principalmente no que diz respeito à valorização do ensino de ciências naturais e das ciências físicoquímicas, ministrado no que veio a se chamar Faculdade de Filosofia (DE AZEVEDO, 1950; FERNANDES, 1978; DE CARVALHO, 1987). Outras arcaísmos: Filosofia Natural era uma designação para vários campos do conhecimento (e.g., Geologia, Química, Zoologia, Botânica e Astronomia), as publicações científicas eram escritas como se fossem obras literárias, em Latim e com perguntas e respostas - às vezes, o autor recorria a um interlocutor imaginário para obter certo ordenamento lógico ao texto. Os estudiosos que se envolviam nesses assuntos e que se saiam bem nas arguições orais ganhavam o título de Philosophiae doctor (PhD).

A instalação das faculdades de Filosofia e o ensino das ciências naturais contribuíram para as mudanças dos costumes, pois logo veio a pesquisa experimental e os cientistas tornaram-se "operários do conhecimento". Como era realizado o ensino nessas unidades? Ele era conduzido de modo bastante artezanal, valorizava-se as pesquisas de campo e os professores não contavam com as comodidades da vida moderna (e.g., Internet, processadores de textos e sistemas informatizado de registros). O trabalho era árduo e os pesquisadores tinham que exibir boa capacidade física para empreender longas expedições ou construção de seus equipamentos; os naturalistas contraiam doenças tropicais, enfrentavam índios bravios e muitos encontraram a morte em suas "viagens filosóficas". O geógrafo Victor Peluso colaborou intensamente para o sucesso da Faculdade Catarinense de Filosofia, como aluno e, posteriormente, como docente no Departamento de Geociências da UFSC. Ele descreveu o modo como suas pesquisas eram realizadas: 
Henrique da Silva Fontes e a criação da Universidade Federal de Santa Catarina

\begin{abstract}
Integrando a campanha das coordenadas geográficas no território catarinense, de 1939 a 1946. Percorri o Estado de Santa Catarina em todos os sentidos. Viajando de ônibus, de caminhão, em lombo de mula, em carro de boi ou em canoas através dos rios encachoeirados, conheci bem a nossa terra. Quando ia ao Rio de Janeiro prestar contas do serviço executado, adquiria livros e frequentava a biblioteca do Conselho (PELUSO, 1986; p. 94).
\end{abstract}

\title{
Fontes e a intelligentsia catarinense
}

O geógrafo Carlos Augusto Monteiro (ver Depoimentos) descreveu o seu ex-chefe como uma pessoa moderna e de cabeça aberta, bem diferente de suas impressões iniciais. A afirmação é condizente com os fatos e os feitos de Henrique Fontes. Deve ser mencionado que o velho desembargador apoiou o movimento modernista em Santa Catarina; uma das lideranças do movimento era o Professor Aníbal Nunes Pires, apontado por ele como um dos fundadores da Faculdade Catarinense de Filosofia. A diferença de idade entre Fontes e os "artes modernas" (como ele designava os jovens escritores e artistas plásticos do grupo Sul) era enorme, mas isso não impedia o afloramento de mútuas simpatias e gestos de apoio.

Os jovens modernistas encontravam resistências entre a elite conservadora e Florianópolis estava mergulhada numa pasmaceira, mas o movimento deu novos direcionamentos às artes plásticas, literatura e teatro. Os membros do grupo Sul reconheciam a importância do apoio de Fontes ao modernismo catarinense; enquanto uns condenavam as inovações artísticas e literárias, ele assistia às palestras, elogiava a produção e, mais importante, dava suporte material (emprego) aos jovens que davam novos rumos à cultura catarinense.

Os modernistas de primeira hora relembram com carinho o relacionamento que tinham com Fontes, o qual acompanhava de perto a evolução do movimento e encontrava oportunidade para exercitar o bom humor, ao mesmo tempo em que sinalizava o interesse: Eglê Malheiros escrevia os poemas e Fontes era um de seus leitores - "D. Eglê, que a senhora não coloque pontos e vírgulas em seus poemas, tudo bem. Mas, arrume alguns pontos e algumas vírgulas para que eu possa ler!”. Em outra ocasião, relembra o escritor Salim Miguel, ele compareceu a uma das palestras organizadas pelos "artes modernas", mas não encontrou o palestrante - eles ficaram bebericando num bar e se esqueceram do evento programado. No dia seguinte, Fontes protestou: "Vejam só o que é arte moderna. Marcam palestras, mas nem mesmo o palestrante comparece! Mas eu compareci!". 


\section{HUMANAS}

O quase-septuagenário Fontes exercia importantes funções públicas e era respeitado pelas autoridades, mas ainda encontrava vigor intelectual para se inteirar do modernismo catarinense que surgira por volta de 1948. Alguns membros do grupo foram acusados de comunistas, despenderam algum tempo na cadeia ou foram demitidos de seus empregos. Aníbal Nunes Pires era professor do Colégio Coração de Jesus, mas as irmãs não renovaram o seu contrato, alegando que o seu perfil não era adequado a um colégio de moças. Com a criação da Faculdade Catarinense de Filosofia, ele é acolhido na novel instituição (GUERRA \& BLASS, 2007).

Fontes exerceu atividades no Instituto Histórico e Geográfico de Santa Catarina, foi membro da Academia Catarinense de Letras e outras agremiações. Foi durante a sua presidência no IHGSC que ocorreu o I Congresso Catarinense de História (1948), evento organizado por ele e Oswaldo Cabral e que teve impacto nacional e internacional. Intelectuais renomados compareceram ao congresso e as discussões marcaram o nascimento ou, pelo menos, deram substancial vigor ao açorianismo - linhas de pesquisa, publicações científicas e festividades que enaltecem o orgulho dos descendentes dos colonizadores oriundos das ilhas dos Açores. Muito se fala na colonização alemã e italiana, mas o orgulho açoriano inexistia ou não tinha a dimensão atual - parece que até existia certo envergonhamento acerca dessa herança. Por outro lado, o sangue dos Açores transbordava nas veias de Fontes e foi ele quem estimulou o conhecimento da diversidade cultural do nosso Estado.

As discussões alimentaram o desejo de criação da Faculdade Catarinense de Filosofia e, conseqüentemente, foi o momento em que as sementes da UFSC foram espalhadas ao solo. O historiador Carlos Humberto Correa (19412010) ofereceu mais detalhes sobre a importância do congresso:

O evento foi organizado por Henrique da Silva Fontes, presidente do IHGSC, e Cabral auxiliou bastante na organização. A idéia inicial era a realização de um congresso para comemorar os 200 anos da imigração açoriana (1748-1948), nada além disso. Até então nada havia sobre o assunto e até mesmo Portugal desconhecia a importância da cultura açoriana em Santa Catarina. Não existia nenhum estudo sobre o assunto e os documentos eram raros ou inexistentes, pois os emigrantes quase todos eram analfabetos e chegaram ao Brasil com a cara e a coragem... Fontes convidou pesquisadores do Brasil e de Portugal, dando oportunidade para a primeira discussão sobre a cultura açoriana e o modo de se estudar a história (In: GUERRA, 2008; p. 56). 


\section{Henrique da Silva Fontes e a criação da Universidade Federal de Santa Catarina}

As universidades modernas não sobrevivem sem as investigações científicas. Ela é uma instituição elitizada, mas a elitização se situa no plano intelectual. Tendo isso em mente, Fontes buscou as melhores inteligências fora de Santa Catarina e do Brasil para compor os quadros da Faculdade Catarinense de Filosofia. É ele quem aponta os fundadores da instituição: Oswaldo Rodrigues Cabral, Padre Alvino Bertholdo Braun, Anibal Nunes Pires, João Batista Luft, Edmundo Accácio Moreira, Jaldyr Bhering Faustino da Silva, Nilson Paulo e Padre Ernesto Seidl. Outros não pertenceram a tal categoria, mas foram colaboradores de primeira hora: Padre Werner José Soell, Cônego Antonio Waterkemper, Padre Francisco de Sales Bianchini, Eudoro de Sousa, Lydio Martinho Callado, Padre Ewaldo Pauli e George Agostinho da Silva (FONTES, 1966). Outros pesquisadores vieram a seguir e contribuiram significativamente para o sucesso da instituição, merecendo destaque Paulo de Araujo Lago, Walter Piazza, Silvio Coelho dos Santos, Raulino Reitez e João Alfredo Rohr. São nomes que se destacaram em sua especialidades e engrandeceram as instituições por onde passaram.

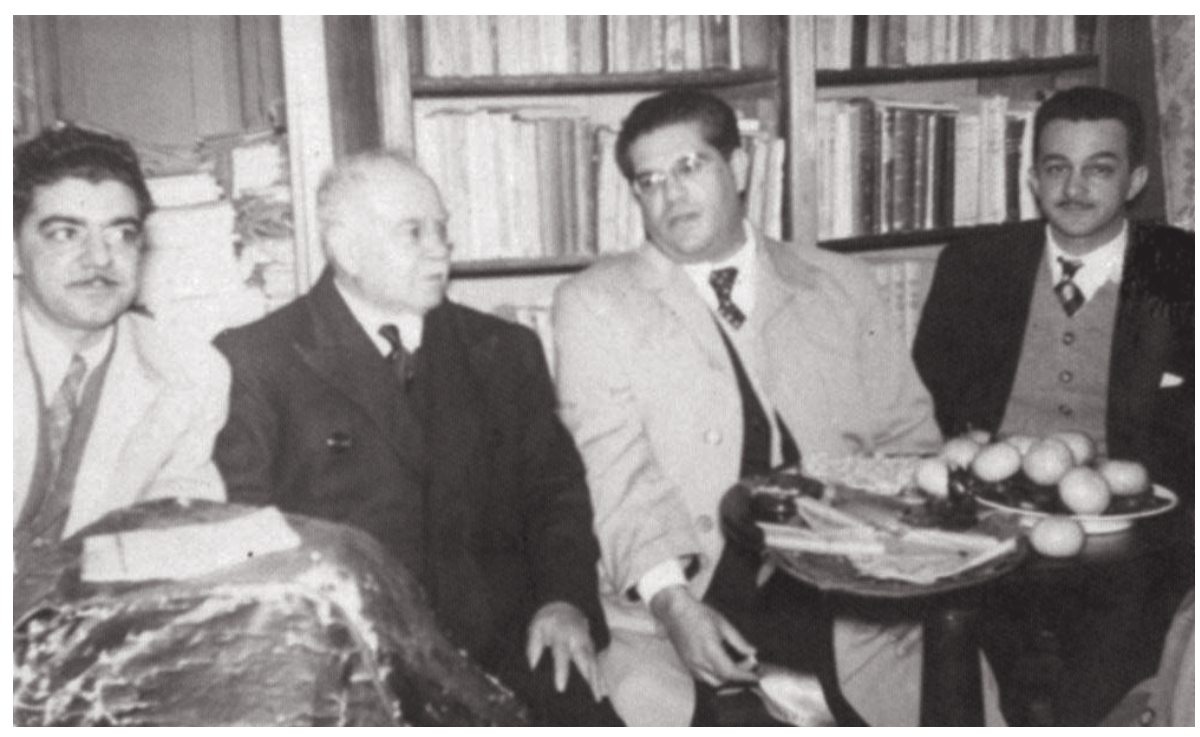

Figura 2

A reunião de amigos na biblioteca particular de Fontes. Da esquerda para a direita: Jau Guedes da Fonseca, Fontes, Roberto Macedo e Acari Silva (29 de Junho de 1949, dia de São Pedro).

O Brasil é um grande exportador de talentos, diferentemente dos EUA e de alguns países da Europa que importam especialistas de alto nível dos países subdesenvolvidos. O fenômeno é uma tragédia e esconde a estupidez institucional, 


\section{HUMANAS}

pois quem cede esses talentos são aqueles que mais deles necessitam, acolheos os países que os têm em abundância. O sonho de muitos jovens talentosos é a migração para os países desenvolvidos, pois eles entendem que o Brasil não reconhece seus méritos ou não oferece as condições necessárias para o desenvolvimento de suas idéias. Os EUA foram enormemente beneficiados com evasões de talentos do mundo inteiro, o que explica o notável desenvolvimento científico e tecnológico desde o final da II Guerra Mundial (GUERRA, 2007). Fontes tinha outras coisas em mente e se lançou numa empresa mais ousada, mais moderna: enquanto o Brasil estava exportando talentos para os países desenvolvidos, o estado de Santa Catarina estava importando-os!

A maior contribuição de Fontes para a criação da universidade foi a formação de uma massa crítica, pois o combustível dessas instituições são as idéias e o arrojo intelectual. A formação de uma equipe de pesquisadores tem efeito multiplicador, pois bons mestres formam bons discípulos e, assim, as instituições ganham vida ou se fortalecem com novas idéias e novas necessidades. Muitos dos antigos professores da Faculdade Catarinense de Filosofia se destacaram em suas especialidades, como Carlos Augusto Monteiro e Armem Mamigonian (ver Depoimentos); outros personagens conhecidos deram aval às idéias de Fontes, como João Dias da Silveira, George Agostinho da Silva e Eudoro de Sousa (CARMINATI, 2009). Os pioneiros publicaram obras relevantes, lideraram equipes em universidades importantes, no Brasil e exterior, e deixaram uma legião de seguidores na atual UFSC. Foi uma extraordinária contribuição de Henrique Fontes, mas, curiosamente, o assunto tem sido pouco examinado.

O modo como Fontes montou a sua equipe de professores foi uma feliz conjugação do mais puro pragmatismo ao espírito de um homem público. Ele entrou em contato com intelectuais perseguidos pela ditadura salazarista e deu plena liberdade de ação a seus auxiliares; João Dias da Silveira e Carlos Augusto Monteiro foram contaminados pelos planos do desembargador e trouxeram outros talentos para encorpar a Faculdade Catarinense de Filosofia. Alguns desses intelectuais tinham militância esquerdista, mas em nenhum momento houve alguma colisão com o espírito aberto e democrático de Fontes ele era católico praticante e seus traços de personalidade sinalizavam "índole conservadora", embora não saibamos o que exatamente isso significa. Essa aparente contradição é outro aspecto de sua mente aberta e moderna.

A autoridade e espírito afável do velho desembargador permitiram a formação de uma equipe de pesquisadores, fator decisivo para o sucesso das unidades acadêmicas. Fontes prestigiava os jovens pesquisadores, dava carta branca aos chefes das unidades e não interferia nas coisas miúdas, conforme relembra Carlos Augusto Monteiro, nome importante da Geografia brasileira e que contava menos de 30 anos quando ingressara nos quadros da Faculdade Catarinense de Filosofia. 


\section{Henrique da Silva Fontes e a criação da Universidade Federal de Santa Catarina}

Os problemas que chegavam ao chefe e que diziam respeito à sua unidade, Fontes despachava de volta e dizia: "Esse assunto é com o Carlos Augusto". $\mathrm{O}$ efeito desse simples procedimento era marcante entre os jovens pesquisadores que trabalhavam com aquele senhor que beirava os 70 anos de idade.

\section{Cidade Universitária}

A Cidade Universitária foi um desdobramento do "Quarteirão Universitário", vislumbrado inicialmente por Fontes ainda nos tempos da Faculdade de Direito. O primeiro prédio a ser posto em funcionamento na Cidade Universitária foi o da Faculdade de Filosofia, Ciências e Letras, a alma mater da universidade que estava sendo partejada. Ele defendeu a aglutinação das unidades num só local, convenceu o Governo Estadual a ceder a Fazenda Modelo Assis Brasil, elaborou o projeto, junto com os engenheiros e arquitetos, e supervisionou diuturnamente as construções até a inauguração dos primeiros prédios.

A centralização das unidades encontrava fortes opositores, mas, em termos acadêmicos e administrativos, era a fórmula mais inteligente e racional. Tal como ocorria nas universidades medievais e nas modernas instituições da Europa e EUA, a proximidade física das unidades acadêmicas facilitava a administração, reduzia os custos operacionais e, mais importante, permitiam o relacionamento dos membros da comunidade - o espírito de uma verdadeira universidade. Os propósitos da Cidade Universitária foram especificados durante a inauguração das instalações da Faculdade de Filosofia, Ciências e Letras:

$$
\begin{aligned}
& \text { Esta construção exemplifica, por outro lado, o con- } \\
& \text { forto e a largueza que a todas proporcionará, a Ci- } \\
& \text { dade Universitária, mergulhando-as em vida ver- } \\
& \text { dadeiramente universitária, pela interação científi- } \\
& \text { ca e administrativa e pela convivência social e fa- } \\
& \text { miliar, e esta vida universitária, na sua unidade es- } \\
& \text { piritual, há de ultrapassar a Cidade Universitária, } \\
& \text { dela fazendo o cérebro e o coração da Ilha de Santa } \\
& \text { Catarina e do Povo Catarinense (FONTES, 1966). }
\end{aligned}
$$

O acerto de suas idéias é inquestionável, pois atualmente ninguém é capaz de defender os afastamentos das unidades e tampouco veríamos algum acerto em mantê-las no centro de Florianópolis, pois o caos urbano se acentuou bastante nas últimas décadas. Fontes acompanhou os desdobramentos das obras, mantinha correspondência com Juscelino Kubitschek e governadores da época. Ele enviava relatórios, justificava os gastos e solicitava recursos adicionais para o prosseguimento das obras e se metia entre os operários, acompanhando o assentamento dos tijolos que davam formas ao seus sonhos. 


\title{
HUMANAS
}

Todos reconhecem que Fontes era um homem meticuloso e que gostava de obras (lembremos que em 1908 ele se matriculou na Escola Politécnica do Rio de Janeiro e tinha desejo de se formar em engenharia), de modo que podemos até julgar que era ele o verdadeiro mestre-de-obras da construção dos prédios da Cidade Universitária.

A UFSC foi instalada entre os bairros Trindade e Pantanal, onde funcionava a Fazenda Modelo Assis Brasil, mantida pelo Governo Estadual. Muito se falava sobre os inconvenientes do local ou da própria centralização das unidades, mas a importância do campus universitário e a rápida urbanização de Florianópolis (uma das capitais com os piores índices de mobilidade urbana) deixaram evidentes o acerto das idéias de Fontes. As estradas eram de barro, as chuvas formavam imensos lamaçais e os ônibus vinham lotados, pois alunos, funcionários e professores compartilhavam o transporte com as lavadeiras de roupas - o local tinha muitos riachos. A mudança do mobiliário foi feita aos poucos e ficou aos encargos do porteiro Joaquim Gonçalves; nenhum vidro foi quebrado durante o percurso de 6 quilômetros, pois os motoristas e operários da Diretoria de Obras Públicas se uniram aos esforços do porteiro. A escolha do local ou a própria idéia do campus foi combatida por João David Ferreira Lima, o primeiro reitor da UFSC. Seus argumentos foram bem sistematizados:

\begin{abstract}
Apenas diremos que, embora julgássemos o local bonito, apresentara elementos negativos, dentre os quais, à época, poderiam ser apontados: a bacia hidrógrafica de um panelão cercado de morros, que obrigaria a obras de canalização e drenagem bastante caras, com conseqüêntes enchentes; terreno alagadiço, que exigiria estaqueamento muito caro para as construções (há prédios de um e dois pavimentos que exigiriam estacas de 25 a 40 metros); a estrada de então, da cidade para a Trindade, era de barro, não havendo quase condução coletiva; serviços de água e luz precários; inexistência de esgoto; local de universidade sediada numa ilha, mas distante do mar e de praias, etc (LIMA, 2000; p. 166).
\end{abstract}

O assunto foi examinado pelo Conselho Universitário, o qual decidiu pela instalação da UFSC no local idealizado por Fontes. Os problemas apontados por Ferreira Lima não são incomuns na Ilha de Santa Catarina e poderiam ser corrigidos (como eles foram) com um bom sistema de drenagem das águas. Muitos prédios surgiram posteriormente na região e, exceto a má-vontade de Ferreira Lima, nada havia de excepcional (i.e., dificuldades técnicas e custos elevados da obras) que justificasse a condenação do local (ver Depoimentos). 
Henrique da Silva Fontes e a criação da Universidade Federal de Santa Catarina

O Governo Estadual já havia cedido o local para a instalação da universidade e, assim sendo, as obras da Faculdade de Filosofia, Ciências e Letras se encontravam bastante adiantadas quando a UFSC emergiu nas páginas do Diário Oficial da União (18 de Dezembro de 1960).

Para elucidar o assunto é interessante mencionar a cronologia dos eventos, pois as datas suscitam certa confusão. A UFSC tem como referência a data de publicação da Lei 3849 (18 de Dezembro de 1960) como o marco de sua criação, mas a aula inaugural (aula magna) e a primeira Assembléia Universitária ocorreram em 15 de Março de 1962; a nomeação de Ferreira Lima ocorreu no dia 9 de Outubro de 1961 e ele tomou posse no dia 25 do mesmo mês. Antes desses eventos, a construção da Cidade Universitária já se encontrava em andamento, tendo sido inaugurado o prédio da Faculdade de Filosofia, Ciências e Letras, cuja construção fora supervisionada por Fontes.

Ferreira Lima manifestara-se contrário à instalação do campus universitário, mas é inconcebível que algo diferente pudesse ter ocorrido, pois, caso os membros do Conselho Universitário decidissem por outra coisa, os dirigentes iriam se deparar com problemas ainda mais graves: as unidades continuariam espalhadas pelo centro de Florianópolis? O que seria feito com a Fazenda Modelo Assis Brasil? Tendo em vista que a Faculdade de Filosofia, Ciências e Letras já havia se transferido para o local, ela, então, seria abandonada naquele "panelão hidrográfico"? Os fatos e a racionalidade favoreceram o projeto inicial de Fontes.

A inauguração da Faculdade Catarinense de Filosofia, Ciências e Letras (novo prédio, novo nome) contou com a presença de autoridades, como o Almirante Augusto H. Rademaker Grünewald, Comandante do $5^{\circ}$ Distrito Naval, o Governador Heriberto Hülse e o Arcebispo Dom Joaquim Domingues de Oliveira; o estudante Domingos Augusto Gaio, Presidente da União Catarinense dos Estudantes também ressaltou a importância do evento. O governador Hülse relembra a importância das ações de Fontes para a implantação da Cidade Universitária e, conseqüentemente, para o sucesso da missão a qual ele fora designado (i.e., a criação da universidade). O discurso é interessante em razão do reconhecimento público e dos adjetivos utilizados para designar o valoroso auxiliar:

Não quero encerrar este discurso, sem render a pública homenagem do meu respeito e da minha admiração a este incansável lidador das nobres causas, ilustre educador, cidadão por todos os títulos benemérito, que é o Professor Henrique da Silva Fontes. Tudo o que aqui se fez e se fará registra a marca do seu espírito sonhador, da sua fecunda obstinação, da sua admirável pertinácia, da sua extraordinária capacidade de querer e de realizar, 
enfim, do seu grande amor a esta terra, que tem servido incansavelmente, com dedicação e com desprendimento. Já tive ensejo de afirmar, neste mesmo local, quando do lançamento da pedra fundamental do edificío que ora se inaugura e aqui repito com satisfação: a melhor e mais edificante lição que os jovens virão recolher nesta Cidade Universitária será a do jovem e pujante idealismo deste velho moço que é o Professor Henrique Fontes (In: FONTES, 1966).

O velho moço parecia estar feliz com a vida. As idéias haviam sido ruminadas na Faculdade de Direito e se materializaram com o sucesso da Faculdade Catarinense de Filosofia e inauguração da Cidade Universitária - o nome original tem significado mais amplo que campus universitário, o que revela a dimensão dos sonhos de Fontes. As instalações eram amplas e confortáveis, para época, e o gabinete do diretor até contava com um telefone! Para provar que a novidade era funcional, as autoridades acompanharam Fontes ao seu gabinete, onde ele realizou uma ligação para a residência e enviou saudações a Dona Clotilde, a esposa que se encontrava adoentada e não pôde comparer à inauguração da Cidade Universitária.

\section{Boiteux, Fontes e Ferreira Lima}

Alguns personagens da vida universitária catarinense foram eclipsados pela ação do tempo, mas é adequado resgatá-los do limbo da história. Tudo teve início com a criação do Instituto Polytechnico, o qual inaugurou o ensino superior em nosso estado e teve à frente José Arthur Boiteux. O governador Heriberto Hülse foi o grande incentivador da criação de uma universidade em Santa Catarina; ele ofereceu todo o suporte necessário ao seu idealizador, Henrique da Silva Fontes, e não ofereceu obstáculos ao ceder a Fazenda Modelo Assis Brasil para a instalação da Universidade de Santa Catarina, mesmo sendo esta deslocada para o organograma federal. JK é homenageado nos eventos da UFSC e até existe um busto dele no saguão da universidade, mas pouco ou nada se fala das ações empreendidas pelo nosso governador.

Fontes e Hülse foram vítimas do esquecimento seletivo, mas qualquer investigação isenta é capaz de constatar a real dimensão de seus feitos. Os dois são pouco lembrados nos eventos comemorativos da UFSC, mas tratase de algo ainda mais lamentável em relação ao Fontes. Ele esteve presente em todos os momentos cruciais da vida da UFSC (i.e., idealização, construção das primeiras unidades e inauguração do campus universitário) e foi o "Encarregado dos estudos da Criação da Universidade de Santa Catarina", 
Henrique da Silva Fontes e a criação da Universidade Federal de Santa Catarina

cargo não-remunerado exercido durante os governos de Irineu Bornhausen (21 de Novembro de 1955), Jorge Lacerda, Heriberto Hülse e Celso Ramos. O desembargador lutou pela idéia, elaborou o projeto e acompanhou os desdobramentos das obras da sua querida Cidade Universitária, mas o local não recebeu o nome de seu idealizador, mas, sim, daquele que se opusera à idéia de instalar as unidades na antiga Fazenda Modelo Assis Brasil - é o Campus Universitário João David Ferreira Lima.

A publicação da Lei 3849 (18 de Desembro de 1960) é algo bastante comemorado pelos antigos dirigentes da UFSC, mas o ato formal só teve consistência devido a existência de uma estrutura em pleno funcionamento (física e intelectual), a qual foi resultante dos esforços que datam da criação do Instituto Polytechnico (1917). A federalização por si só não equivale ao processo de criação da UFSC, pois as unidades existentes foram aglutinadas, tal como ocorreu em outras partes do país, e o processo lhes deu o status de universidade (ver VASCONCELOS, 2007). É verdade que o ato formal permitiu o surgimento de novas unidades, mas a federalização só foi possível tendo em vista as unidades que se encontravam em pleno funcionamento.

A federalização é algo bastante comemorado na UFSC, mas a tendência era parte de uma política governamental e já vinha sendo adotada no início da década 1950, momento em que surgem algumas universidades federais (e.g., UFPr, UFCe, UFPa, UFBa e UFRGS). O processo ganha mais intensidade no início da década seguinte, quando surgem a UFSC e as universidades federais da Paraíba (13 de Dezembro de 1960), do Rio Grande do Norte (18 de Dezembro de 1960), do Espírito Santo (30 de Janeiro de 1961), de Alagoas (18 de Dezembro de 1961) e a Universidade Federal Fluminense (22 de Dezembro de 1960); o processo não ficou restrito às capitais, pois Juiz de Fora/MG e Santa Maria/RS também ganharam suas universidades federais em 1960. A Universidade de Brasília (15 de Dezembro de 1961), idealizada pelos educadores Anisio Teixeira e Darcy Ribeiro, foi uma grande novidade, mas também foi resultante do processo de federalização do ensino superior.

JK foi um presidente extraordinário, mas a sua política estava voltada para o país inteiro; ele não tinha nenhum relacionamento especial com Santa Catarina e tampouco as autoridades do Ministério da Educação foram especialmente sensibilizados pelos nossos argumentos acerca da importância de uma universidade federal no estado. A federalização foi algo natural ou até quase forçado, mas fundamentais foram os eventos que antecederam ao processo. Com efeito, é importante ressaltar que a UFSC não nasceu com o ato formalizado no Diário Oficial, mas foi resultante de três empreendimentos amplos e complexos: o cultivo de uma idéia (sensibilização da sociedade e das autoridades catarinenses acerca da importância de uma universidade), o desenvolvimento de uma massa crítica (a aglutinação de intelectuais em torno do projeto) 


\section{HUMANAS}

e a operacionalização das idéias (i.e., a criação da Faculdade Catarinense de Filosofia e a aglutinação das unidades no atual Campus Universitário da Trindade). Os passos foram sequenciados e tiveram início com a malograda experiência do Instituto Polytechnico (1917) e o sucesso da Faculdade de Direito (1932). Fontes foi o personagem mais importante na história da UFSC, mas seria injusto não lembrar o papel desempenhado por José Artur Boiteux, "Patriarca do Ensino Superior", e o apoio irrelutante do Governador Heriberto Hülse.

Os personagens mais próximos da UFSC foram Fontes e Ferreira Lima, ou o verdadeiro patrono da universidade e o mais dinâmico dos reitores. O primeiro foi injustamente esquecido com os desdobramentos da história da UFSC, mas é preciso relembrar seus méritos. Boiteux e Fontes são pouco mencionados no livro de Ferreira Lima (2000) e, nas poucas vezes que isso ocorre, o saldo não lhes é favorável. Boiteux exerceu importantes funções públicas, liderou a criação da primeira instituição de ensino superior no estado (Instituto Polytechnico, 1917) e fundou a Academia Catarinense de Letras e o Instituto Histórico e Geográfico de Santa Catarina. São coisas extraordinárias, mas Ferreira Lima o designa como idealista ingênuo. No que diz respeito a Fontes, ele informa que os esforços deste para a construção da Cidade Universitária se limitara a "colocar estacas para sinalizar os pontos onde as unidades seriam construídas" e que havia insistido junto ao mesmo para unir esforços em prol da universidade federal, como se a federalização fosse uma coisa extraordinária e Fontes um novato no assunto. Ferreira Lima ainda postulou que a instituição pioneira do ensino superior catarinense foi a Faculdade de Direito (esqueceu os esforços de Boiteux na criação do Instituto Polytechnico e o papel desempenhado por Fontes na criação e administação da própria Faculdade de Direito) e que fora ele, junto com os amigos, que idealizara, criara e administrara a UFSC até 25 de Outubro de 1971.

A UFSC recentemente comemorou os 50 anos de sua existência (19602010). Os eventos foram marcados por distribuições de diplomas e medalhas aos antigos membros da comunidade ou àqueles que as unidades julgaram ser merecedores de alguma homenagem. Muitas das distinções são protocolares ou estão condenadas ao esquecimento num breve espaço de tempo, pois elas têm significado gerontocrático ou são motivadas pela ocupação de um cargo eletivo circunstancial e efêmero. Parece que se entende que a UFSC surgiu no vácuo e que a história das antigas faculdades não tem nenhuma conexão com a nossa instituição.

Pioneiros de grande valor foram esquecidos, mas houve até oportunidade para outorga do título de doutor Honoris causa a Fritz Müller (1821-97), naturalista alemão que se estabeleceu na região de Blumenau. Trata-se de algo inusitado que em nada engrandece a figura desse conhecido naturalista e parece mais servir para dar relevância às solenidades dos 50 anos da UFSC. 


\section{Henrique da Silva Fontes e a criação da Universidade Federal de Santa Catarina}

Uma vistosa exposição de fotografias de ex-reitores foi inaugurada no saguão do prédio da Reitoria, mas esqueceu-se dos personagens mais significativos e mais próximos da nossa história universitária, como José Arthur Boiteux, Henrique da Silva Fontes e Heriberto Hülse.

\section{O recolhimento do velho moço}

Na última reunião da Congregação da Faculdade de Filosofia ( 8 de Fevereiro de 1961, antes da mudança para a Cidade Universitária), Fontes se despede da vida acadêmica. Ele contava com quase 76 anos, mas ainda tinha energia suficiente para enfrentar a enorme confusão administrativa e liderar os primeiros passos da universidade. As unidades federalizadas deram origem à UFSC, mas Ferreira Lima foi designado para o cargo de reitor algum tempo depois (toma posse em 25 de Outubro de 1961). Tudo ocorreu às pressas e o processo de escolha foi muito simplificado; houve até a publicação no Diário Oficial da União (22 de Agosto de 1961) da nomeação de João Bayer Filho para responder como reitor da Universidade de Santa Catarina, assinada por Jânio Quadros, sucessor de JK (LIMA, 2000). Enquanto isso, Fontes continuava o seu trabalho à frente da construção dos novos prédios e direção de sua unidade; o vácuo administrativo e as responsabilidades de seu cargo forçavam-no a agir como reitor pro tempore. Com a mudança do governo estadual, o "Encarregado dos Estudos da Criação da Universidade" envia o relatório (3 de Novembro de 1961) a Celso Ramos, o novo governador:

Instalada, como felizmente está, a Universidade de Santa Catarina, criada pela Lei Federal n. 3.849, de 18 de dezembro de 1960, e subordinada ao Estatuto aprovado pelo Decreto n. 50.580, de 12 de maio de 1961, ficou sem objeto a função de Encarregado dos respectivos estudos, instituída no art. $9^{\circ}$ da Lei Estadual n. 1.362, de 29 de outubro de 1955, função gratuita que venho exercendo desde 26 de novembro do mesmo ano. Tive a honra de ser confirmado por Vossa Excelência e em suas mãos, Senhor Governador, agora deponho, apresentando sucinto relatório das atividades que me foi possível desenvolver(FONTES, 1966).

O relatório é minucioso no que diz respeito às aplicações dos recursos orçamentários e o surgimento gradativo das construções. A discriminação das despesas revela as longas viagens que Fontes realizava ao Rio de Janeiro, 


\title{
HUMANAS
}

a capital do país e onde funcionava o Conselho Nacional de Educação e à Diretoria de Ensino Superior. Ele viajava de onibus e usava os recursos do próprio bolso para custeá-las - o único privilégio que ele solicitava ao Governo Estadual era a liberação do filho Jorge da Luz Fontes, consultor jurídico, para lhe prestar ajuda nas questões legais ou proporcionar suporte emocional ao supra-septuagenário.

É importante destacar as diferenças de idade e os métodos de atuação de Fontes (1885-1966) e Ferreira Lima (1910-2001): um estava encerrando a carreira acadêmica e o outro, em pleno vigor da maturidade intelectual; um viajava de ônibus e o outro, de avião (Ferreira Lima era diretor da empresa Transporte Aéreos Catarinenses e tinha passagens gratuitas). Não obstante os anos lhe pesando nas costas, Fontes manteve as responsabilidades de "Encarregado dos estudos da criação da Universidade de Santa Catarina" até o momento em que ela se materializou nos documentos oficiais. É verdade que os trabalhos se prolongaram durante o novo Governo Estadual, pois existia muita confusão, poeira, operários transitando de lá para cá e relatórios a serem providenciados. Na última reunião da Congregação ( 8 de Fevereiro de 1961), ele busca inspiração no significativo sermão de São Francisco de Assis para justificar o seu recolhimento:

\begin{abstract}
Dou graças a Deus, por ter permitido que eu assistisse ao progresso do ensino e da educação popular em Santa Catarina e que dele também participasse durante meio século. Esta participação mesmo que a Irmã Morte ou a Irmã Doença de mim se apoderem, cessará brevemente, no ato da federalização da Faculdade, por força do imperativo legal da idade; mas eu terei a alegria de repetir as palavras do velho Simeão, ao contemplar o Messias: “Agora, Senhor, deixas partir o teu servo em paz, segundo a tua palavra" (FONTES, 1966).
\end{abstract}

Algum tempo depois, na colação de grau da primeira turma do curso de Licenciatura (8 de Setembro de 1961), Fontes justificou o uso parcimonioso das palavras, alegando os avanços da idade e o temperamento afetivo. É a ocasião em que ele incita os jovens ao otimismo e ao cumprimento do dever. O comovido Fontes relembra que a sua longa missão no magistério está por se findar, mas deixa aos jovens uma Cidade Universitária "espaçosa, tranqüila, hospitaleira, linda e alegre". É o seu discurso de despedida. Oswaldo Cabral assume a direção da Faculdade de Filosofia, Ciências e Letras e, no discurso proferido durante a colação de grau dos bacharéis (6 de Dezembro de 1961), ele enaltece o idealismo e a abnegação do velho mestre e, curiosamente, utiliza certas palavras como se Fontes fosse o reitor da UFSC. 


\section{Henrique da Silva Fontes e a criação da Universidade Federal de Santa Catarina}

A quem poderíamos outorgar o título de criador da UFSC? A instituição emergiu a partir da aglutinação de unidades já existentes, o modelo tinha como eixo estruturante a Faculdade de Filosofia, Ciências e Letras, as obras da Cidade Universitária já estavam em andamento e, mais importante, o estado de Santa Catarina já dispunha de uma elite acadêmica capaz de levar adiante a missão universitária. É importante ressaltar que o sonho universitário não emergiu espontaneamente a partir das nomeações do Diário Oficial, mas germinou sistematicamente a partir das discussões ocorridas no I Congresso de História (1948) e da criação da Faculdade Catarinense de Filosofia (1951), eventos conduzidos por Fontes e que consolidaram os sonhos universitários.

\section{Por que o velho moço deve ser reverenciado?}

As universidades são lembradas por seus prédios imponentes, jardins floridos e jovens circulando pelo campus, mas elas só ganham vida a partir da qualidade dos trabalhos desenvolvidos por uma elite intelectual. Fontes dedicou a sua vida ao ensino (produção de livros e cartilhas, discursos e artigos de jornais) e foi o pioneiro na implantação do ensino universitário em Santa Catarina. A existência do atual Campus Universitário se deve unicamente às suas ações e a sua memória está indelevelmente associado a duas unidades bastante atuantes: o Centro de Ciências Jurídicas (antiga Faculdade de Direito) e o Centro de Filosofia e Ciências Humanas (antiga Faculdade Catarinense de Filosofia). Nenhum personagem de nossa instituição ostenta tais credenciais.

Os cientistas lidam rotineiramente com a evolução das idéias (i.e., hipóteses, leis e teorias) e entendem que os avanços do conhecimento se devem à reunião de pessoas capacitadas em torno de um problema ou linha de pesquisa - usualmente designado de massa crítica; nada surge no vácuo, tampouco as instituições nascem através de geração espontânea. Os amigos do Desembargador Fontes reconhecem que ele foi uma pessoa extraordinária e que deu fundamental contribuição para a implantação do ensino universitário em Santa Catarina; ele era um homem que tinha idéias. Esses amigos também lamentam o esquecimento das ações de Fontes, mais ainda o fato de ele não ter sido o primeiro reitor da instituição; alguns explicam isso como decorrente da idade, outros atribuem às preferências politico-partidárias (ver Depoimentos), mas é razoável supor que as duas coisas se somaram. Parece que Fontes não sentia desconforto com os novos rumos da UFSC e seus discursos já anunciavam o seu o recolhimento. Não obstante tudo isso, o resultado final é o seguinte: cada vez que cavoucamos os documentos oficiais e examinamos os efeitos práticos das ações do Desembargador Fontes, nós constamos a importância desse extraordinário personagem da nossa vida acadêmica. 


\section{UMANAS}

\section{Agradecimentos}

Alguns intelectuais contribuíram para o surgimento deste texto, seja intermediando os depoimentos de pessoas que conheceram pessoalmente Henrique Fontes, seja procedendo a uma leitura cuidadosa da versão preliminar. O projeto ganhou força com os estímulos e informações oferecidas por Arno Blass, Carlos Humberto Correa, Flavio José Cardozo, Norberto Ulyssea Ungaretti, Raquel Maria Fontes do Amaral Pereira e Salim Miguel. As conversas com Armen Mamigonian, Carlos Augusto Monteiro e Olavo Arantes permitiram melhor entendimento acerca da importância dos feitos do Desembargador Fontes. Um agradecimento especial é dirigido a Aurora Goulart e Theresinha de Jesus da Luz Fontes: a primeira se encontrava hospitalizada, mas mesmo assim aceitou fornecer um depoimento sobre o ex-chefe, e a segunda permitiu o acesso ao acervo documental de seu pai.

\section{Referências bibliográficas}

BLASS, A. \& GUERRA, R.F. Caspar Erich Stemmer e o desenvolvimento científico e tecnológico no Brasil. Revista de Ciências Humanas, 41(1/2): 9-46, 2007.

BYRD, M.D. Back to the future for higher education medieval universities. The Internet and Higher Education, 4: 1-7, 2001.

CARMINATI, C.J. Intelectuais e políticos na expansão do ensino superior catarinense na década de 1950. Revista Linhas, 10(1): 148-159, 2009.

CASTRO, C.M. Ciência e universidade. Rio de Janeiro: Jorge Zahar Editor, 1985.

CASTRO, F.M.O. A matemática no Brasil. In: F. de Azevedo (Org.). As ciências no Brasil. Volume 1, pp. 57-96. Rio de Janeiro: Editora da UFRJ, 1950.

DE AZEVEDO, F. Brazilian culture. Nova York: The MacMillan Co., 1950.

DE CARVALHO, R. A história natural em Portugal no século XVIII. Lisboa: Instituto de Cultura e Língua Portuguesa, 1987.

FAVERO, M.L.A. A universidade no Brasil: das origens à Reforma Universitária de 1968. Educar, 28: 17-36, 2006.

FERNANDES, R. O pensamento pedagógico em Portugal. Lisboa: Instituto de Cultura e Língua Portuguesa, 1978. 


\section{Henrique da Silva Fontes e a criação da Universidade Federal de Santa Catarina}

FONSECA FILHO, O. Uma controvérsia descabida. Separata do tomo II de “Oswaldo Cruz Monumenta Historica”. São Paulo, 1974.

FONTES, H.S. Pensamentos, palavras e obras. Florianópolis: Edição do Autor, 1962.

GARDINER, J. \& WENBORN, N. (Eds.). The history today companion to British history. Londres: Collins \& Brown, 1995.

GUERRA, R.F. Educação científica e desperdício de talentos. Universidade e Sociedade, 39: 124-135, 2007.

GUERRA, R.F. Oswaldo Rodrigues Cabral - notas sobre a trajetória de vida de um intelectual brilhante. Revista de Ciências Humanas, 42(1/2): 9-60, 2008.

GUERRA, R.F. \& BLASS, A. Grupo Sul e a revolução modernista em Santa Catarina. Revista de Ciências Humanas, 43(1): 9-95, 2009.

LENT, H. In memoriam - Arthur Neiva (1880-1943). Revista Brasileira de Biologia, 3(3): 273-91, 1943.

LEONARDOS, O.H. A mineralogia e a petrografia no Brasil. In: F. de Azevedo (Org.). As ciências no Brasil. Volume 1, pp. 297-347. Rio de Janeiro: Editora da UFRJ, 1950.

LIMA, J.D.F. UFSC: sonho e realidade. Florianópolis: EdUFSC, 2000.

MARTINS, J.T. A biologia no Brasil. In: F. de Azevedo (Org.). As ciências no Brasil. Volume 2. Rio de Janeiro: Editora da UFRJ, 1950.

MENDONÇA, A.W.P.C. A universidade no Brasil. Revista Brasileira de Educação, 14: 131-50, 2000.

PELUSO, JR., V.A. Entrevista concedida a C.A.F. Monteiro, A. Manigonian, O.G. da Silva, A.M. Prates e M.D. Buss. Geosul, 1: 90-105, 1986.

PERKIN, H. History of universities. In: J.J.F. Forest \& P.G. Altbach (Eds.). International handbook of higher education. Pp. 159-205. Nova York: Springer, 2007.

ROSA, J.E. \& MADEIRA, A.A. Instituto Polytechnico - primeira instituição de ensino superior no Estado de Santa Catarina. Revista Catarinense de Odontologia, 5(1): 30-40, 1978.

SCHWARTZMAN, S. Ciência, universidade e ideologia. Rio de Janeiro: Zahar Editores, 1980. 


\section{HUMANAS}

VASCONCELOS, I.M. A federalização do ensino superior no Brasil. Dissertação de Mestrado, Departamento de Sociologia. Brasília: Universidade de Brasília, 2007.

VERGER, J. As universidades na Idade Média. São Paulo: Editora da UNESP, 1990.

\section{Depoimentos}

\section{Carlos Augusto de Figueiredo Monteiro}

Ele nasceu em Teresina/PI, em 23 de Março/1927. É um dos principais geógrafos e climatologistas do Brasil. Ele concluiu o Doutoramento (1967), a Livre-Docência (1975) e a Titulação (1985) em Geografia na Universidade de São Paulo; Monteiro se formou em Geografia e História (1950) na Faculdade Nacional de Filosofia da Universidade do Brasil, atualmente Universidade Federal do Rio de Janeiro. É autor de várias obras que deram renome à Geografia brasileira. Atuou como estagiário do Laboratório de Geomorfologia (École Pratique de Hautes Études) e no Laboratório de Sedimentologia (École Nationale d'Agronomie), ambos na França (1951-53). Estimulados por colegas e sob a chefia do Desembargador Henrique Fontes, ele assume o cargo de professor de Geografia Física na Faculdade Catarinense de Filosofia (1955-59), atualmente Centro de Filosofia e Ciências Humanas da Universidade Federal de Santa Catarina. Após esse período, Monteiro assume outras funções na Faculdade de Filosofia, Ciências e Letras de Rio Claro (1960-64), uma das unidades que deram origem à Universidade Estadual Paulista "Júlio de Mesquita Filho", UNESP. Ele também foi professor de Geomorfologia no Instituto de Ciências da Universidade de Brasília (196667); atuou no Departamento de Geografia da Universidade de São Paulo (1968), onde foi o responsável pelas disciplinas de Geografia Física até a aposentadoria (1987). Monteiro é autor de vários livros, entre os quais Geografia sempre - o homem e seus mundos (2008), A questão ambiental na geografia do Brasil (2003), O mapa e a trama - ensaios sobre o conteúdo geográfico em criações romanescas (2002), Clima urbano (2002), Geossistemas - história de uma procura (2001), O estudo geográfico do clima (1999) e Clima e excepcionalismo - conjecturas sobre o desempenho da atmosfera como fenômeno geográfico (1991). Ele foi professor visitante da Universidade de Tsukuba (1982-83) e os seus méritos foram reconhecidos pela Universidade de São Paulo (Professor Emérito) e universidades federais do Rio de Janeiro e do Piaui (Doutor Honoris causa). 


\section{Henrique da Silva Fontes e a criação da Universidade Federal de Santa Catarina}

As contribuições de Monteiro às geociências foram destacadas numa importante obra sobre a história das ciências no Brasil ${ }^{6}$.

RCH - Como foi o início de sua carreira?

Monteiro - Eu me graduei (Bacharel e Licenciatura) em Geografia e História (1950) na Faculdade de Filosofia da então Universidade do Brasil. No dia Finados do ano seguinte, eu embarquei no navio Lavoisier e fui para a França, onde despendi dois anos beneficiado por uma bolsa de estudo; a viagem durou 15 dias - naquela época só gente rica viajava nos aviões da Pan Air. O meu objetivo era complementar as deficiências de minha formação. Na graduação, meu interesse inicial era a História do Brasil, mas não existia nenhum programa de iniciação às pesquisas; os professores eram muito formais e ninguém era estimulado a consultar os arquivos e as fontes originais. Assim sendo, eu acabei me dirigindo para a Geografia, onde o ensino era mais dinâmico e nós contávamos com um professor francês muito dedicado, o qual vivera no Japão cerca de quatro anos e tivera oportunidade de estudar o maciço da região Kuan-sai. Ele também estivera em Cuba e, com a eclosão da II Guerra Mundial, acabou ficando retido no Brasil. Ele escapara do front, mas nós lucramos com isso. Este professor também foi consultor do IBGE e ministrou aulas de Geomorfologia na Universidade de Brasília, permanecendo no Brasil por um período de 14 anos.

RCH - Por que o interesse pela Geografia?

Monteiro - O Brasil era o único ou um dos raros países que tinham uma instituição que se preocupava com a geografia e com a coleta de informações estatísticas (IBGE), subordinada à cúpula governamental. Informações dessa natureza eram consideradas fundamentais para a administração e implantação de políticas públicas, principalmente no que diz respeito à soberania nacional, divisão territorial, produção agrícola e outras coisas. Isso representou enorme salto para a geografia: ela deixava de ser descritiva para interpretativa. A geração de novos geógrafos que havia surgido no Rio de Janeiro, capital do país, e na Universidade de São Paulo era idealista e bastante motivada. Por outro lado, a geografia praticada no Instituto Histórico e Geográfico era jocosamente designada como "A veneranda"; isso marcava nitidamente as diferenças entre as duas gerações.

Eu me formei na Universidade do Brasil e complementei meus estudos na França. Ao retornar da pós-graduação (1953), eu fiquei decepcionado com os rumos do IBGE: a instituição não passava por bons momentos, não realizava excursões e pesquisas de campos. O fenômeno ocorre com muitas instituições no Brasil, pois elas mudam com o tempo e passam por fases boas e ruins.

${ }^{6}$ Ab'Saber, A.N. \& Christofoletti, A. Geociências. In: M.G. Ferri \& S. Motoyama (Coords.). História das ciências no Brasil. p. 117-238. São Paulo: EPU e EdUSP, 1979. 


\section{HUMANAS}

Nessa ocasião, eu estava profundamente decepcionado com os rumos do IBGE e, então, pensei: "acho que vou procurar outra coisa". Eu até pensei em me submeter a um emprego na Companhia de Navegação, visando conhecer o mundo. As coisas estavam muito paradas.

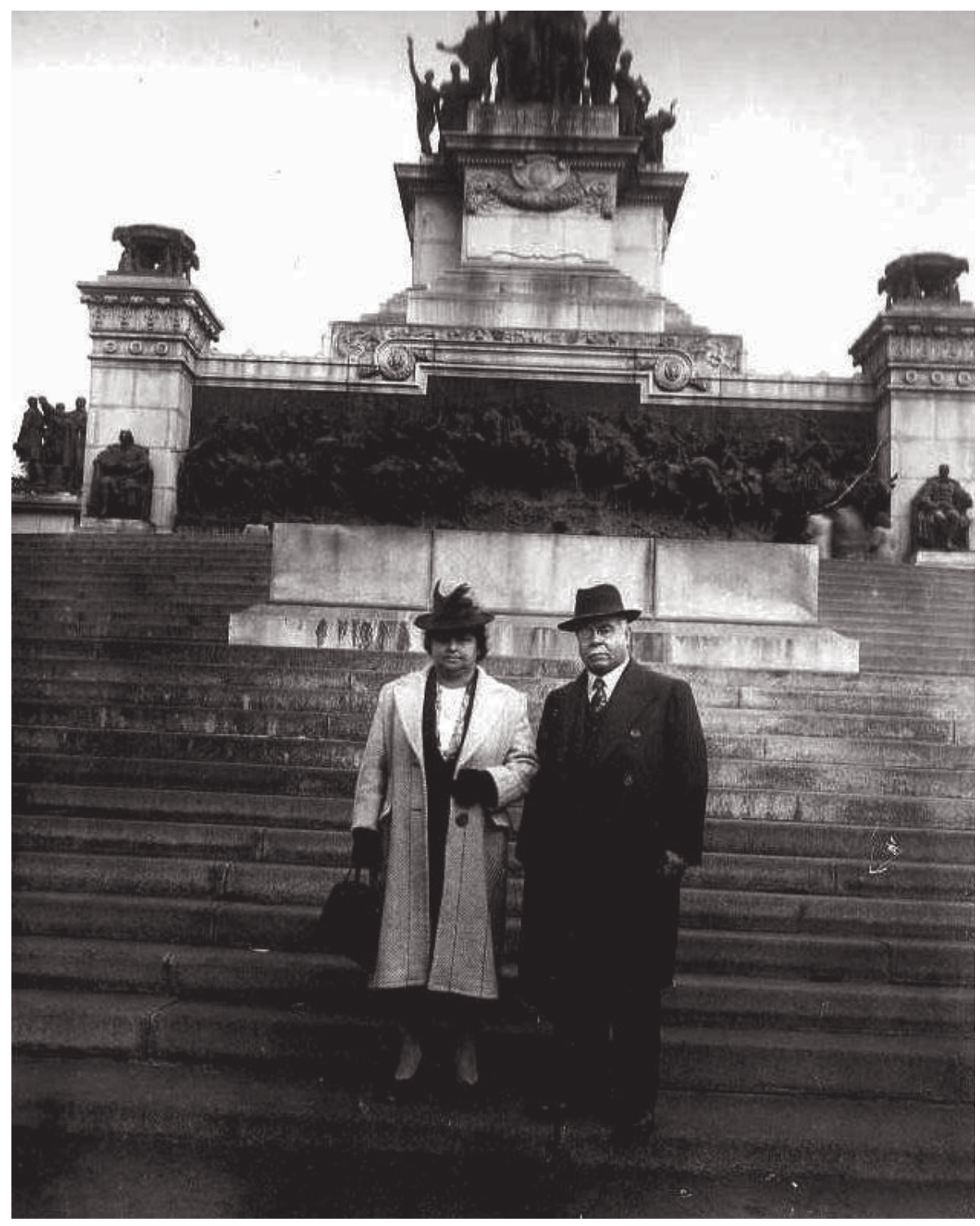

Figura 3

Fontes e sua esposa, Dona Clotilde Arminda Born da Luz Fontes, em visita ao Museu do Ipiranga (São Paulo, Agosto de 1943). 


\section{Henrique da Silva Fontes e a criação da Universidade Federal de Santa Catarina}

RCH - Foi nessa ocasião que ocorreu o contato com o Desembargador Henrique Fontes e a Faculdade de Filosofia?

Monteiro - Nessa ocasião, uma amiga entrou em contato e me alertou sobre a criação de uma instituição em Santa Catarina. Era Maria Conceição Vicente de Carvalho, a primeira doutora em Geografia do Brasil e assistente do Professor Pierre Monbeig (1908-87); ela era filha do conhecido poeta Vicente de Carvalho (1866-1924). O que aconteceu foi o seguinte: durante um congresso de História, em Porto Alegre/RS, Conceição se encontrara com João Dias da Silveira, Professor Catedrático de Geografia Física da USP e que havia sido liberado pelo governo estadual paulista para colaborar com Santa Catarina. O objetivo era implantar um curso de Geografia em Florianópolis, o qual era parte da Faculdade de Filosofia que o Professor Henrique da Silva Fontes estava implantando no Estado. Fontes havia atingido a aposentadoria compulsória na Faculdade de Direito e tinha em mente a criação de uma universidade em Santa Catarina; um dos passos necessários e fundamentais para o empreendimento é a criação de uma faculdade de Filosofia e Ciências. A criação de uma universidade era um sonho antigo, mas quem deu os passos definitivos foi o Professor Fontes. A Faculdade de Filosofia foi instalada num prédio vizinho ao Colégio Catarinense e contou com a colaboração de vários padres jesuítas desta instituição, graças ao prestígio de Fontes. Outro intelectual que contribuiu bastante com o projeto foi Oswaldo Rodrigues Cabral (1903-78), que era conhecido no meio político e acadêmico e tinha várias obras publicadas sobre antropologia e história de Santa Catarina.

RCH - Como foram os anos iniciais da Faculdade de Filosofia?

Monteiro - Fontes tinha em mente algo mais amplo e mais complexo: a criação de uma universidade em Santa Catarina. Ele estava dando os passos fundamentais, pois a faculdade de Filosofia era um núcleo obrigatório - não era permitido a implantação de uma universidade sem uma Faculdade de Filosofia, Ciências e Letras, tal como ocorreu com a USP e UnB. A instituição contou com os subsídios do governo estadual, pois Fontes tinha prestígio e conseguiu sensibilizar as autoridades acerca da importância de seu projeto. Ele era um intelectual conhecido e estava acima dos conflitos e das questões políticas, embora o seu filho, Paulo Fontes, fosse um político afiliado à UDN; o Desembargador Fontes era bastante respeitado e circulava livremente pelos gabinetes.

Eu tome conhecimento do projeto a partir das conversas com Maria Conceição, a qual me disse: "Olha, o Professor João Dias da Silveira está com um problema. Ele estava colaborando com Santa Catarina, mas Jânio Quadros (1955-59) assumiu o governo do Estado de São Paulo e está convocando todos os funcionários que se encontram à disposição de outros Estados para retornarem às funções em São Paulo". Silveira se encontrava nessa situação e, 


\section{HUMANAS}

portanto, a sua colaboração com o estado de Santa Catarina deveria ser interrompida. Ele estava procurando um substituto para ministrar disciplinas de Geografia Física, área que contava com poucos especialistas na época. Maria da Conceição queria saber se eu tinha algum interesse na vaga, pois eu tinha formação adequada e vinha trabalhando no campo da Climatologia. Antes de tomar uma decisão, eu entrei em contato com Silveira, o qual me explicou detalhadamente a natureza do projeto, disse o que estava fazendo e apresentou-me ao desembargador. Eu aceitei os novos encargos e Fontes ficou entusiasmado com a minha aceitação, pois a titulação dos professores disponíveis era pobre e, em contrapartida, eu tinha pós-graduação na França.

RCH - Como eram realizados essas contratações?

Monteiro - A Faculdade de Filosofia ganhava novos alunos e Fontes teve que usar suas habilidades para contratar os professores para as disciplinas. Ele insistia em prestigiar a "prata da casa" que mais se destacava, entre os quais Oswaldo Cabral, mas sabia que o pessoal de fora era "sangue novo" e era importante para os seus propósitos. Foi agindo assim que ele trouxe George Agostinho da Silva e Eudoro de Sousa, renomados intelectuais portugueses evadidos da ditadura de Salazar. Fontes considerava que, por exemplo, para o ensino de língua espanhola nada melhor que uma pessoa da Espanha para ministrar as aulas - e foi isso que ocorreu.

RCH - ...E suas impressões iniciais acerca da cidade?

Monteiro - Eu simpatizei de imediato com Florianópolis, pois a cidade era um paraíso. Embora fosse a capital do estado, ela era muito pacata e parecia ser uma cidade do interior: as moças faziam o footing na Praça XV, do Palácio do Governo ao Ponto Chic. A ponte Hercílio Luz funcionava regularmente e os poucos automóveis competiam com as carroças e charretes-de-burro. Tudo era agradável, pitoresco. Eu cheguei ao final de 1955 e inicialmente me instalei num hotel, depois num apartamento e em seguida numa casa no bairro Coqueiros. O primeiro ano de Geografia e História já estava em funcionamento, Silveira estava retornando à São Paulo e eu iria assumir o curso de Geografia Física, ao mesmo tempo em que fui designado para outras funções. Silveira era bastante ativo e organizado, pois se envolvia com assuntos relacionados à administração, ampliação do acervo bibliográfico, construção dos armários e mesas. Ele tinha carta branca do Desembargador Fontes e, ao retornar à São Paulo, eu assumi todos os seus encargos na Faculdade de Filosofia, referente à Geografia e História.

RCH - V. ainda manteve o vínculo com o IBGE?

Monteiro - Como eu lhe disse anteriormente, eu estava desgostoso com a instituição e havia pedido ao meu amigo, o geógrafo Nilo Bernardes, 
Henrique da Silva Fontes e a criação da Universidade Federal de Santa Catarina

uma licença de dois anos sem vencimentos - esse era o procedimento a ser adotado para não perder o vínculo empregatício. Bernardes dirigia o órgão e propôs uma solução diferente: "Não será preciso o pedido de licenciamento, pois Santa Catarina é um dos poucos estados da Federação que dispõe de escritório de Geografia e Cartografia". Dessa forma, eu mantive as minhas funções e pude assumir os encargos na recém-criada Faculdade de Filosofia. O IBGE era subordinado diretamente à Presidência da República e os especialistas se reuniam regularmente. Os encontros contavam com a participação de representantes dos ministérios, das diversas secretarias e dos estados. Eu me lembro que o representante do Itamaraty era J. Guimarães Rosa (1908-67); do Ministério da Educação era Carlos Miguel Delgado de Carvalho (1884-1990), grande geógrafo. Essas reuniões ocorriam para decidir assuntos variados, como a mudança de nome dos municípios, desmembramentos e delimitações territoriais. Santa Catarina era um dos poucos estados que contavam com uma instituição que tratava desses assuntos. O Departamento de Geografia e Cartografia era vinculado ao IBGE e havia sido criado e dirigido por Victor Peluso Júnior (1909-94), ilustre intelectual catarinense. Tal como Oswaldo Cabral, Peluso já tinha publicado vários livros, era respeitado e reconhecido como notório saber. Peluso havia se formado como agrimensor e buscou especialização no Geological Survey (Washington, EUA); ele aproveitou a oportunidade para adquirir uma vasta coleção de livros clássicos, que se revelou muito útil para o acervo do futuro Departamento de Geografia e Cartografia do Estado de Santa Catarina. As atividades do Peluso eram variadas: ele elaborava os mapas, cuidava da parte geodésica, realizava pesquisas de campo e permanecia atento à administração de seu departamento.

RCH - Como v. se desdobrava nos dois empregos?

Monteiro - Quando eu assumi as funções em Santa Catarina, eu encontrei o departamento instalado num sobrado antigo, exatamente onde foi construído o atual Hotel Flop, em frente à casa de Nereu Ramos; as manhãs eu despendia no Departamento de Geografia e Cartografia, à tarde trabalhava e às noites ministrava aulas na Faculdade Catarinense de Filosofia, Nessa ocasião, o Departamento de Cartografia e Geografia era chefiado pelo Carlos Büchele Jr., pois Victor Peluso havia assumido a Secretaria de Planejamento no governo de Irineu Bornhausen (1951-56). Peluso era bastante prestigiado pelo governador e, certa ocasião, num momento de crise, chegou a responder por três pastas (Planejamento, Educação e Agricultura).

RCH - Como era o seu relacionamento com Peluso?

Monteiro - Ele já contava com vários títulos publicados e era reconhecido como autoridade em sua especialidade, mas foi capaz de um gesto que me causou bastante admiração. Com efeito, ele já era quarentão, 


\section{HUMANAS}

tinha obras publicadas e poderia atuar como professor na Faculdade de Filosofia, mas matriculou-se e freqüentou o curso como simples aluno (1956-59) e entre colegas que tinham a metade de sua idade. Foi um gesto admirável que me deixou sensibilizado. Os professores e alunos até brincavam com aquilo, anunciando que qualquer problema poderia ser resolvido imediatamente, na hora, pois o secretário se encontrava presente na sala de aula! É claro que Peluso tinha muitos problemas, pois era convocado para reuniões importantes ou era obrigado a viajar repentinamente para cumprir a agenda oficial, mas ele era inteligente e facilmente dava conta das tarefas acadêmicas. Quando as coisas apertavam, eu the dizia: "Sinto muito, secretário, mas a sua nota não passará de cinco!". Ele era uma pessoa admirável e aceitava com bom humor.

RCH - Descreva a sua experiência administrativa, a chefia do Departamento de Geografia.

Monteiro - Em 1957, Geografia e História se separaram e a última levou a melhor. Muitos alunos migraram para o novo curso de História e eu cheguei a ter apenas dois alunos matriculados nas minhas disciplinas - Lucita Freiesleben, moça inteligente que fora minha assistente e que, desafortunadamente, já é falecida, e Arlene Maykot. Além das aulas e dos encargos no Departamento de Geografia e Cartografia, eu tive que organizar e administrar o recém criado Departamento de Geografia, sem esquecer as tumultuadas reuniões da congregação. Eu comecei por onde os outros geralmente terminam: a administração. Uma de minhas tarefas era convidar e selecionar professores para as disciplinas, como Geografia do Brasil que não tinha professor. Paulo Fernando de Araujo Lago (1931-2002) era um colega mais jovem e se encontrava em Valença, no estado do Rio de Janeiro; eu escrevi uma carta e ele aceitou o convite. O Professor João Dias da Silveira indicou Armen Mamigonian e Francisco Takeda, recém-formado em Geologia; Cecília França contribuiu para a disciplina de Geografia Humana, em substituição a uma professora que estava retornando à São Paulo. O grupo foi se formando gradativamente; nós éramos jovens e tínhamos como aluno Victor Peluso, o Secretário de Planejamento do Governo Estadual! A experiência na Chefia do Departamento foi problemática e eu acabei me vacinando contra os cargos administrativos. Nunca mais fui seduzido a assumir funções equivalentes! Eu passei 20 anos na USP e nunca dirigi algum órgão, exceto o meu laboratório e minha equipe de pesquisa.

RCH - Quais eram as deficiências iniciais?

Monteiro - Nós tínhamos muitas deficiências. Éramos jovens e inexperientes e o curso era uma novidade. A colega Cecília França dizia que se sentia muito mal ministrando aulas naquelas condições, pois a Universidade de Bordeaux dispunha do Professor Papy para ensinar Geografia Humana e ela, por seu turno, 


\section{Henrique da Silva Fontes e a criação da Universidade Federal de Santa Catarina}

sem nenhuma experiência estava assumindo as mesmas funções. Eu lhe disse: "Cecília, cada pessoa tem o seu tempo e sua história!" Eu não me sentia diminuído ministrando aulas, pois sabia que o curso era deficiente e que nós não podíamos nos comparar aos professores da França. Eu sabia e dizia para ela que nós tínhamos que estudar! O meu período em Florianópolis envolveu a administração do Departamento de Geografia, ensino de disciplinas de Geografia Física e as funções no Departamento de Cartografia, filiado ao IBGE. Apesar das dificuldades, nós conseguimos finalizar um atlas do Estado de Santa Catarina, o primeiro dessa natureza e que teve ampla aceitação. Ele contou com a colaboração de algumas pessoas: nós utilizamos uma impressora multilith que Peluso havia comprado, um técnico competente - o Sr. Espírito Santo - realizou o milagre de dar cores aos mapas; eles eram levados duas ou três vezes à impressora para se obter a coloração desejada. Os resultados foram além de satisfatórios e inspirou outros estados a produzirem atlas de seus territórios.

RCH - A publicação do atlas foi uma notável contribuição, mas como a idéia foi materializada?

Monteiro - A elaboração do atlas era o desejo de Carlos Büchele Jr., então chefe do Departamento de Cartografia e Geografia do Estado de Santa Catarina. Ele foi publicado com a valiosa colaboração de Armen Mamigonian (1958) e contou ainda com a participação de outros colegas: Francisco Takeda ficou responsável pelos mapas geológicos; Paulo Lago analisou a atividade pesquei$\mathrm{ra}$, interesse que permaneceu ao longo de sua carreira. $\mathrm{O}$ atlas era pequeno, mas continha mapas geomorfológicos e climáticos e as cores permitiam boa compreensão. Foi uma novidade: alguns Estados pediram exemplares e até Portugal se interessou pelo nosso atlas; ele teve boa aceitação e, com efeito, o IBGE estimulou os demais Estados da Federação a elaborar algo parecido. O nosso modelo inspirou a elaboração de atlas variados, o que foi uma contribuição interessante de Santa Catarina; até então, não existia nada equivalente aqui e nos demais estados. Após isso, eu acabei me dirigindo para a Climatologia, área mais carente de especialistas; a Geomorfologia contava com grandes nomes, como Aziz Ab'Saber (1924- ) e João José Bigarella (1923- ), em contraste com as deficiências da Climatologia. Em Santa Catarina, eu me debrucei nas obras dos antigos meteorologistas brasileiros e me preparei bastante para ministrar aulas de Climatologia, diferente daquela que eu havia estudado na França e que era largamente praticada no Brasil.

RCH - ... E onde entra o Desembargador Fontes nessas histórias?

Monteiro - É importante ressaltar que nada disso seria realizado se eu não contasse com o apoio irrestrito de Fontes. Eu confesso que não tive boa impressão dele nos contatos iniciais: aquele senhor baixinho, com bastante idade e 


\section{HUMANAS}

de atitudes formais levaram-me a concluir que eu teria sérias dificuldades no exercício de minhas funções; eu associava o Fontes às coisas arcaicas e conservadoras. Foi um enorme engano, pois ele era exatamente o oposto: Fontes tinha uma cabeça moderna, adorava e promovia festas e conduzia a Faculdade de Filosofia como se fosse algo de sua família. Eudoro de Sousa (1911-87) e sua esposa faziam bacalhoadas e bolinhos, os alunos e professores participavam desses encontros e o ambiente era extremamente agradável. O Desembargador queria que todos se dessem bem e que a convivência fosse a mais harmoniosa possível. Ele era uma pessoa aberta aos diálogos e aceitava tudo que revertesse em beneficio da faculdade.

RCH - Do ponto de vista pessoal, você se dava bem com Fontes?

Monteiro - A minha relação com ele era muito boa, excelente. Eu nunca entrei em desacordo com Fontes e tinha carta branca para realizar tudo o que fosse necessário. Em relação aos assuntos de minha especialidade, ele sempre dizia: "Esse assunto é com o Carlos Augusto." Eu era jovem, sentia-me prestigiado e uma grande admiração emergiu naturalmente. Eu gostava tanto do Fontes que resolvi convidá-lo para ser meu padrinho da Crisma - os planos não prosperaram, pois, infelizmente, eu tive que retornar à São Paulo e até hoje não fui crismado! Eu nunca tive um chefe que me causasse tanta admiração, pois ele era o modelo de um grande homem, pessoa extraordinária. Fontes foi secretário da Educação, contribuiu decisivamente para a criação da Faculdade de Direito (1932) e ainda encontrou tempo para escrever uma cartilha para alfabetização de crianças. A sua vida inteira foi dedicada à educação.

RCH - Como era Florianópolis nos anos 1950?

Monteiro - Durante todos os 84 anos de minha vida, informo-lhe que o período mais feliz foram os cinco anos que despendi trabalhando sob a chefia de Fontes, em Florianópolis. Eu completei 30 anos aqui, estava amadurecendo e me aceitando, contava com um emprego que me obrigava a produzir e tudo o que eu fazia era valorizado pelo desembargador. Foi maravilhoso. Eu adorava Florianópolis. A produção intelectual era precária e a cidade perdia em importância para Joinville e Blumenau - ela parecia ser capital apenas para os açorianos! A cidade se transformou bastante, mas, embora tenha adquirido alguns problemas dos grandes centros urbanos, ela continua bela e atraente. Na época, a vida social era estimulada pela presença do $5^{\circ}$ Distrito naval, Escola de Aprendizes Marinheiros e unidades do Exército e da Aeronáutica - o Dia do Almirante Tamandaré era comemorado com bailes, o que agitava um pouco a cidade. Florianópolis era bastante provinciana, mas era um paraíso. As pessoas se deslocavam em "carrinhos de mola" (espécie de taxi puxado por um cavalo) e, certa ocasião, ocorreu um fato pitoresco com Fontes. 


\section{Henrique da Silva Fontes e a criação da Universidade Federal de Santa Catarina}

Ele recorria aos "carrinhos de mola" para se deslocar de um lugar a outro e as corridas eram cobradas de acordo com o tamanho do percurso. Num desses deslocamentos, ele percebeu certo exagero na cobrança do serviço, mas pagou sem protestar. O episódio foi relatado aos amigos na Faculdade de Filosofia e logo surgiu uma anedota: "É claro que um burro conduzindo outro burro o valor da corrida é dobrado!" Fontes não se aborrecia com os risos, pois o seu aspecto sisudo e formal escondia uma personalidade bem humorada.

RCH - ... E o seu retorno à São Paulo? Quais foram as circunstâncias?

Monteiro - Eu estava bem integrado na Faculdade de Filosofia, gostava muito de Florianópolis e tinha uma profunda admiração pelo Desembargador Fontes, mas, curiosamente, foram esses fatores que promoveram o meu retorno a São Paulo. Eu adorava o meu emprego, foi aqui que eu completei meus 30 anos, comemorei a vitória do Brasil na copa de 1958 e até havia adotado, para desgosto de alguns colegas, o Figueirense como time preferido. Surge um enigma: foram os anos mais felizes da minha vida e, então, por que eu me desliguei da faculdade e dirigi-me à São Paulo? Foi uma conjugação de dúvidas e incertezas. Eu tinha horror às desavenças e intrigas, a instituição estava sendo federalizada e sabia que Fontes não assumiria a direção da nova unidade - ele tinha atingido a compulsória. Eu tinha minhas dúvidas se me daria bem com o novo diretor, de modo que eu solicitei a rescisão de meu contrato; Fontes contraargumentou e acabou me concedendo uma licença de dois anos, sem vencimentos. Eu fui para Rio Claro/SP e, mais tarde, soube que minhas suspeitas tinham fundamento, pois houve muita confusão na Faculdade de Filosofia.

RCH - Como foi a sua atuação em Rio Claro?

Monteiro - Em 1960, João Dias da Silveira, que havia indicado o meu nome para ocupar as funções em Florianópolis, estava criando um Faculdade de Filosofia Ciências e Letras em Rio Claro. Era uma experiência que havia sido iniciada no governo de Jânio Quadros (1955-59) e que tivera continuidade no governo de Carlos Alberto Carvalho Pinto (1959-63). A intenção era criar institutos de ensino superior no estado de São Paulo; eram institutos isolados, cada um direcionado a uma especialidade: Rio Claro tinha as ciências práticas (Biologia, Geografia e História), Assis era mais direcionado para as Letras (aonde Antonio Cândido, conhecido crítico literário, chegou a ministrar aulas); Ribeirão Preto foi mais direcionado para a Medicina e Ciências Biológicas. As unidades foram se multiplicando e, mais tarde, foram aglutinadas e deram origem à Universidade Estadual Paulista "Júlio de Mesquita Filho" (UNESP). Nessa ocasião, Silveira entrou em contato e lançou novo convite: "Carlos Augusto, você não deseja trabalhar em Rio Claro?" e eu lhe disse: "Professor, você me colocou para trabalhar em Florianópolis, onde estou me dando muito bem. 


\section{HUMANAS}

Agora quer que eu me mude de novo?" Ele argumentou que eu ficaria mais próximo de São Paulo e isso permitiria que eu avançasse no doutoramento, sob sua orientação. Por outro lado, eu percebia que Fontes, malgrado todos os seus esforços para a criação da UFSC, logo seria substituído. Assim sendo, eu aceitei o novo convite de Silveira.

RCH - Era o nascimento da Universidade Federal de Santa Catarina?

Monteiro - Fontes usava a sua influência no governo estadual para criar a universidade. Ele conseguiu um terreno para situar o campus - a Fazenda Modelo Assis Brasil, entre os bairros Trindade e Pantanal. Ele estava há muito tempo envolvido no projeto e freqüentemente viajava ao Rio de Janeiro, então capital do país e onde estava o Ministério da Educação, para tratar de assuntos relacionados à criação da universidade. Um triste episódio revela claramente a dimensão de seu envolvimento nesse projeto. Como eu lhe disse anteriormente, as viagens à capital da República eram freqüentes e demoradas e numa dessas ocasiões ele recebeu um telegrama anunciando o falecimento de uma de suas filhas - Alba Maria da Luz Fontes Piazza, ocorrido em 8 de Maio de 1959, devido a complicações do parto. O Desembargador foi pego de surpresa e a família informou que o sepultamente seria postergado até a sua chegada, mas ele reagiu de modo surpreendente. Ele respondeu que estava realizando uma tarefa importante para Santa Catarina, algo que traria benefícios aos catarinenses, e que a sua presença não traria a filha de volta. Os filhos deveriam providenciar o sepultamente e ele iria enfrentar sozinho as suas dores, sem interromper a sua missão. $\mathrm{O}$ episódio mostra bem a natureza de seu caráter, o envolvimento com a Educação e o amor à Santa Catarina.

RCH - ... Membros mais antigos da comunidade acadêmica reconhecem a importância do Desembargador Fontes, mas se queixam do esquecimento de seus feitos. Qual é a sua opinião acerca desses lapsos mnemônicos?

Monteiro - Fontes fez tudo o que era necessário para a criação da UFSC: ele elaborou o projeto, deus os passos iniciais e defendeu ardorosamente a criação do campus universitário na Fazenda Modelo Assis Brasil. A Faculdade de Filosofia já se encontrava em pleno funcionamento e foi ele quem conseguiu o terreno para instalação do campus, embora muitos não tenham defendido tal idéia. Fontes era uma pessoa admirável. Ele era professor de Direito, desembargador e ainda encontrou tempo para escrever uma cartilha para alfabetização de crianças; ele já contava com muitos anos vividos e poderia saborear tranquilamente a aposentadoria, mas resolveu liderar um projeto de enorme significado para a vida cultural de Santa Catarina. Ele ainda tinha interesse pelo significado e origem etimológica dos nomes pessoais; sua filha, Theresinha, chegava a brincar com tal interesse: "Há anos que papai vem se dedicando a esse projeto, mas ainda não passou da letra A!". 


\section{Henrique da Silva Fontes e a criação da Universidade Federal de Santa Catarina}

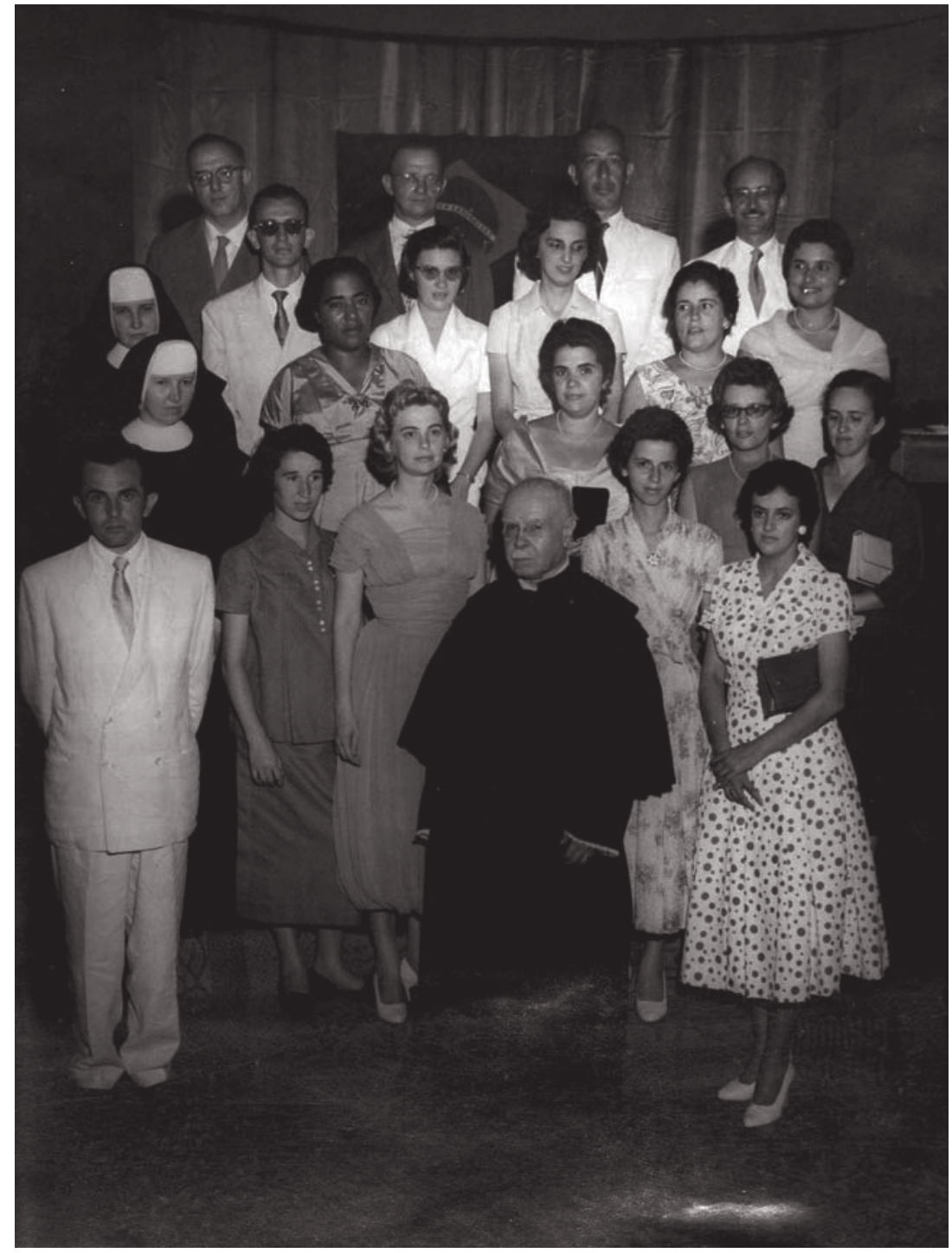

Figura 4

Colação de grau da primeira turma de bacharéis do curso de Filosofia (11 de Janeiro de 1958). Da esquerda para a direita, de cima para baixo: Giovanni Pasqualino Faraco, José Warken Filho, Antenor Luz, Telmo Vieira Ribeiro, Maria Agnes Heinen (Irmã Mariana), Walter Fernando Piazza, Marly Anna Fortes Bustamante, Ivonne Christoval, Dilza Délia Dutra, Hend Miguel, Irene Reckziegel (Irmã Artúris), Matilde Vieira,

Oswaldina Cabral Gomes, Olga Cruz, Alba Maria da Silveira, Celestino Sachet (orador), Therezinha de Jesus Sachet, Dinah Fernandes Brognoli, Theresinha de Jesus da Luz Fontes (ver Depoimentos) e Anna Therezinha Maria Sanford Lins. A figura central é o Desembargador Fontes, o paraninfo da turma. 


\section{HUMANAs}

\section{Armen Mamigonian}

Nasceu na capital do estado de São Paulo, em 25 de Abril/1935, oriundo de família armênia. Ele iniciou o curso secundário em Campo Grande (MS) e concluiu no Colégio Mackenzie (SP); Armen obteve a graduação em Geografia e História (1956) e se especializou em Geografia Humana (1959), ambos na Universidade de São Paulo. O doutoramento em Geografia Industrial foi realizado na Universidade de Estrasburgo (França, 1962); o pós-doutoramento foi realizado na Université Paris 1 (Panthéon-Sorbone, 1984). Nome conhecido da geografia, Armen é autor de alguns livros importantes, entre os quais China: um bilhão de habitantes (1990) e organizador de $O$ pensamento de Ignacio Rangel (1998). Ele foi um dos primeiros colaboradores da Faculdade Catarinense de Filosofia e manteve relacionamento próximo com Henrique da Silva Fontes; mais tarde, ele se transfere para a Universidade de São Paulo, onde obtém a Livre-Docência (2005). Armen é autor de várias contribuições científicas (livros, artigos e orientações de teses de Mestrado e Doutoramento); ele é pesquisador do CNPq (nível 1A), professor visitante da Université Paris 1) e colabora o Programa de Pós-Graduação do Departamento de Geociências, da UFSC.

RCH - Qual era o significado da criação da UFSC?

Armen - Todos nós sabemos que a instalação da Faculdade de Filosofia era um passo obrigatório para a criação de uma universidade; era parte da legislação federal tal requisito nos anos 1930 . Todas as universidades foram criadas de acordo com a legislação, como ocorreu com a Universidade de São Paulo e a UFRJ; elas tiveram que seguir a legislação e recorreram aos professores estrangeiros para compor os quadros. A pesquisa pura era realizada na Faculdade de Filosofia, diferentemente das outras unidades que eram mais voltadas para a pesquisa aplicada ou tecnológica. Em São Paulo, por exemplo, a geologia era praticada na Escola Politécnica, mas a geologia pura era encontrada nos cursos de História Natural da Faculdade de Filosofia.

RCH - O mesmo processo ocorreu na USP?

Armen - A Faculdade de Filosofia foi patrocinada por Júlio de Mesquita Filho, influente jornalista proprietário do jornal O Estado de São Paulo. Ele era cunhado de Armando de Salles Oliveira, governador nomeado pelo presidente Getulio Vargas. Mesquita tinha prestígio e força para angariar os fundos para a criação da Faculdade de Filosofia; ele tinha amigos na Europa e contatou intelectuais importantes para ministrar aulas na USP, entre os quais Roger Bastide (1898-1974), Pierre Monbeig (1908-87), Claude Levi-Strauss (1908-2009), Fernand Braudel (1902-85) e outros. O Desembargador Henrique Fontes tinha idéias bem parecidas, 
Henrique da Silva Fontes e a criação da Universidade Federal de Santa Catarina

embora tenha tido problemas para custear os salários dos professores estrangeiros ou de outros estados. Eles recebiam salário acima do salário do pessoal daqui, algo necessário, pois eles vinham de fora e não tinham outras fontes de renda. Para contornar as dificuldades orçamentárias, Fontes teve que recorrer à "prata da casa", como Oswaldo Cabral (1903-78), o qual tinha bom nível e já tinha visitado os EUA; Victor Antonio Peluso Júnior (1909-94) também já era conhecido e era um intelectual de alto nível, mas preferiu cursar Geografia na recém-criada faculdade.

RCH - E também buscou talentos espalhados pelo Brasil...

Armen - Sim. Alguns professores "pratas da casa" tinham boa qualificação, mas outros não eram lá essas coisas ou eram meio devagar... Fontes sabia que não podia contar unicamente com esse pessoal e, portanto, saiu em busca de professores de outros estados e alguns estrangeiros. O salário era razoável, bem acima do salário pago aos professores de Florianópolis, o que gerou bastante ciumeira.

RCH - Quem eram esses professores?

Armen - Os professores de fora tinham titulação adequada e, de modo geral, eram jovens promissores. Fontes buscou pessoas de alto nível, no Rio de Janeiro. Ele entrou em contato com alguns intelectuais portugueses exilados da ditadura salazarista, como George Agostinho da Silva (1906-94) e Eudoro de Sousa (1911-87); eles eram católicos e tinham ligação com os padres do Rio de Janeiro. Ambos eram de altíssimo nível, bem acima da qualidade da "prata da casa". Por exemplo, Agostinho publicou um estudo sobre Fernando Pessoa, a qual se tornou famosa após a sua saída de Santa Catarina; Eudoro traduziu do grego os filósofos publicados pela Editora Globo. Por seu turno, os iniciantes também tinham bom nome e os títulos necessários, como ocorreu com João Evangelista de Andrade Filho, que ficou responsável pela disciplina História da Arte; ele foi diretor do Museu de Arte de Santa Catarina e conseguiu trazer uma tela importante de Victor Meirelles à Florianópolis. Por seu turno, Carlos Augusto Monteiro havia cursado uma pós-graduação de alto nível e sua capacidade já era conhecida. Os iniciantes eram jovens e tinham um futuro promissor, conforme ficou comprovado com desenvolvimento de suas carreiras. Em síntese: esse era o pessoal que Fontes havia escolhido para dar início à Faculdade Catarinense de Filosofia.

RCH - O que ocorreu a partir da saída de Fontes?

Armen - A partir do momento que Oswaldo Cabral substitui Fontes na direção da Faculdade de Filosofia, ele implanta certos procedimentos que causaram confusão. Cabral instalou um relógio de ponto para os professores, 
UMANAS

sem que ele próprio se submetesse a tal controle - ele "trabalhava" ao mesmo tempo na Faculdade de Filosofia e no INSS, como médico. Isso causou irritação entre os professores. Anteriormente, por ocasião da saída do Professor Agostinho, o próprio indicou um substituto para o seu lugar; ele estava indo para Bahia - onde fundou um centro de estudos afro-asiáticos, bastante ativo até os dias atuais - e indicou Joaquim Montezuma de Carvalho (1928-2008) para ocupar o seu lugar. Montezuma era um crítico literário que se encontrava trabalhando no jornal $O$ Estado de São Paulo, igualmente português e exilado da ditadura salazarista. Fontes aceita a recomendação de Agostinho e submeteu o nome de Montezuma à Congregação, mas Cabral e os professores "pratas da casa" impedem a aprovação, em favor de Oswaldo de Mello que trabalhava com folclore e que tinha se formado em Direito. Fontes vetou a proposta com o argumento: "Esse rapaz tem de estudar mais para lecionar aqui".

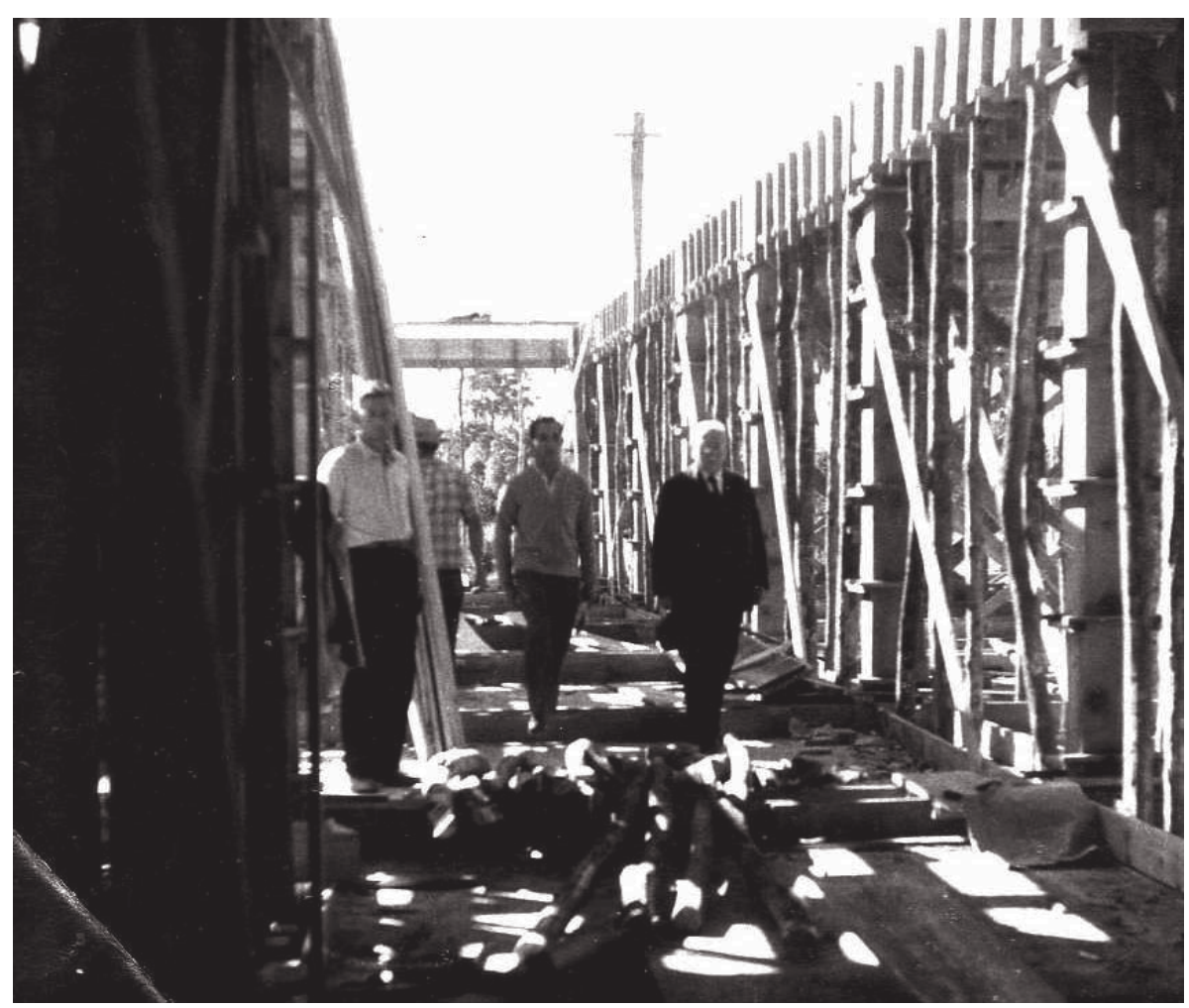

Figura 5

"Eu assisti a toda essa labuta e posso dar testemunho" - Fontes vistoriando, ao lado do mestre-de-obras Emídio Pamplona e do engenheiro Lineo Machado, a construção do prédio da Faculdade de Filosofia, Ciências e Letras na Cidade Universitária (final de 1959). 


\section{Henrique da Silva Fontes e a criação da Universidade Federal de Santa Catarina}

RCH - Qual é a sua impressão acerca do Professor Fontes?

Armen - Ele foi um grande educador e foi quem planejou, lutou e deu os passos necessários para a criação da UFSC. João David Ferreira Lima, o primeiro reitor, era contrário à instalação do campus universitário na Trindade e só assumiu os encargos a posteriori, mas se tornou conhecido como o "fundador" da instituição. Ele era afiliado ao PSD, partido do presidente Juscelino Kubitschek, usufruia da confiança do ex-governador Aderbal Ramos da Silva, igualmente filiado ao PSD, e por isto ele foi nomeado.

\section{Aurora Goulart}

Ela nasceu em 1 de Março de 1924, natural de São José, município ligado à Florianópolis. Dona Aurora concluiu o curso Normal no Instituto Estadual de Educação (1951), equivalente ao $2^{\circ} \mathrm{Grau}$. Naquela época, os rapazes ingressavam no Científico e as moças, por falta de opções ou porque se interessavam pelo magistério, se tornavam normalistas. Após isso, ela ministra aulas em Ituporanga/SC e se torna diretora do Grupo Escolar Alberto Santos Dumont, em Blumenau/SC. Em 1955, Fontes solicita ao Governo Estadual (gestão Irineu Bornhausen) que Dona Aurora fosse colocada à disposição da Faculdade Catarinense de Filosofia. Ela foi secretária, elaborava as atas das reuniões da Congregação e atendia aos alunos; ela tinha sala própria, atendia aos visitantes e mantinha contato permanente com os professores, especialmente com o seu chefe imediato, o Desembargador Fontes. Além das funções administrativas, ela encontrou tempo para frequentar a primeira turma do Bacherelado e Licenciatura do curso de Letras Neolatinas (1955-59). Com o surgimento da UFSC, ela é indicada por George Agostinho da Silva para ministrar a disciplina Literatura Portuguesa, permanecendo nos novos encargos até a aposentadoria (1984). Dona Aurora informou que não fora secretária pessoal do Prof. Fontes, mas ela conviveu muito tempo com o seu chefe e lançou comentários interessantes sobre os anos iniciais da Faculdade Catarinende de Filosofia.

RCH - Como era o dia-a-dia do Desembargador?

Aurora - Fontes era uma pessoa idosa, mas trabalhava continuamente e não desperdiçava o seu tempo e suas energias. Ele recebia bem as pessoas, as quais vinham para perguntar sobre a faculdade; tudo era uma novidade e as pessoas queriam conhecer melhor a instituição. Fontes também atendia aos alunos e professores, sempre de modo cordial e atencioso. Ele cuidava de seu trabalho com muito carinho e parecia que nós pertenciamos a sua família. Ele usou a sua influência para contratar os melhores professores para os cursos de História e Geografia, Filosofia e Letras. Nós trabalhávamos com documentos manuscritos ou datilografados, existia a rotina administrativa e uma de minhas 


\section{HUMANAS}

funções era participar das reuniões da Congregação, a fim de anotar as informações, redigir as atas e levar os documentos para os professores assinarem. Os documentos eram redigidos e, porteriormente, datilografados na máquina de escrever. Eu não posso dizer que era propriamente a secretária do Professor Fontes, mas fazia o que ele me pedia e exercia outras funções. Eu tinha a minha sala, atendia ao público e comunicava aos professores as deliberações da Congregação. Às vezes, ele aparecia e me dizia: "Vá ao curso de Geografia e fale com o professor tal..." Eu tinha o meu horário normal de trabalho, mas muitas vezes permanecia mais tempo na faculdade para elaborar as atas ou para finalizar outras tarefas; o ambiente era agradável, as pessoas se davam bem e o trabalho não era fatigante. Eu gostava daquele ambiente.

RCH - Dona Aurora, fale um pouco sobre a personalidade de seu chefe.

Aurora - Fontes tinha o seu gabinete de trabalho entre o corredor e a sala da Congregação, onde recebia os professores e aos alunos que a ele recorriam. Ele era uma pessoa séria e pouco expansiva, mas todo mundo gostava dele e ele sabia proporcionar o lazer necessário. Fontes trabalhava intensamente, apesar de idoso, mas incentivava as alunas do curso de Letras - algumas cozinhavam muito bem! - a fazer o almoço comunitário, envolvendo os funcionários, professores e alunos dos cursos. Nós tinhamos momentos de lazer e as festinhas eram realizadas de modo comedido, de acordo com os princípios da correção.

RCH - Como era o seu envolvimento com o projeto de criação da universidade? Aurora - Eu não conheço detalhes do projeto, mas eu percebia que ele tinha enorme entusiasmo pela criação de uma universidade em Santa Catarina; esse era o seu sonho e ele trabalhou muito no projeto. A criação de uma faculdade de Filosofia era requisito necessário para o sucesso do projeto, pois já existiam algumas faculdades em funcionamento (Direito, Ciências Econômicas, Farmácia e Odontologia), e o quadro ficaria completo com a Faculdade Catarinense de Filosofia; ela surgiu em 1951, mas começou a funcionar de fato em 1955. Outros estados já estavam bastante avançados no ensino superior e o Professor Fontes não desejava que Santa Catarina fosse deixada para trás. Ele realizou várias viagens ao Rio de Janeiro, manteve contatos com as autoridades do Ministério da Educação e contratou professores de renome, como George Agostinho da Silva e Eudoro de Sousa; outros vieram a seguir. Esses professores aceitaram participar da implantação da Faculdade Catarinense de Filosofia, pois confiavam plenamente no Professor Fontes; ele sabia como aglutinar as pessoas, contou com a ajuda dos padres do Colégio Catarinense e usou a influência para compor os quadros necessários aos cursos. Alguns professores catarinenses já usufruíam bom conceito, como Oswaldo Cabral e alguns padres jesuítas - por exemplo, ele convidou o Cônego Antonio Waterkemper para ministrar aulas de Latim no curso de Letras. 
Henrique da Silva Fontes e a criação da Universidade Federal de Santa Catarina

RCH - Fontes deveria ser o primeiro reitor da Universidade Federal de Santa Catarina, mas isso não ocorreu. Os amigos exibem desconforto sobre o assunto, de modo que gostaríamos de alguns esclarecimentos.

Aurora - A Faculdade de Filosofia foi instalada num prédio em frente à Reitoria (1961). Eu fiquei bastante emocionada com a mudança, pois eu cheguei ao local e encontrei Fontes já trabalhando. Nessa ocasião eu pude perceber que ele não tinha condições para levar adiante os trabalhos - ele era bastante idoso, tinha 76 anos. Apesar de seu idealismo e amor à instituição, ele não tinha energia para assumir os encargos e havia ultrapassado o limite de idade nos quadros do funcionalismo público. Alguns falam que houve perseguição política ou que ele perdeu a Reitoria devido aos interesses políticos, mas não houve nada disso. Fontes era uma pessoa respeitada, tinha prestígio junto às autoridades e ninguém se atreveria a vetar o seu nome; ele estava acima dessas questões. Não obstante o esquecimento de seu nome, foi ele quem plantou as sementes e liderou o processo que culminou na implantação da UFSC. Eu acho que ele não foi nomeado reitor simplesmente devido à idade avançada.

\section{Olavo Fontana Arantes}

Ele nasceu em 27 de Abril de 1930, em Monte Azul Paulista/SP. O $2^{\circ}$ Grau foi realizado no Colégio Estadual Otoniel Mota, em Ribeirão Preto; graduou-se em Engenharia Civil, na Universidade Federal do Paraná (1956). Após a conclusão do curso, Arantes imediatamente é contratado pelo Governo Estadual de Santa Catarina (Março/1957), ocasião em que ele assume algumas obras, entre as quais a construção da Cidade Universitária, e estabelece relacionamento com o Desembargador Henrique Fontes; outros personagens que ele mantinha contato eram Otto Henrich Entres, Diretor de Obras Públicas, e o Governador Heriberto Hülse. Com o tempo, Arantes assume mais encargos na Diretoria de Obras Públicas (DOP) e se torna responsável por muitas obras no Estado de Santa Catarina. O seu currículo conta com mais de $2.000 .000 \mathrm{~m}^{2}$ de área construída, merecendo destaque as construções dos prédios da Assembléia Legislativa, do Tribunal de Justiça, do Tribunal de Contas, da Imprensa Oficial e da Secretaria de Educação; ele se especializou em construções de hospitais e usou seus conhecimentos para edificação de oito unidades, entre os quais os hospitais Celso Ramos, São José e Joana de Gusmão - em razão dos detalhes técnicos, complexidade dos ambientes e função social, são essas unidades que mais despertam o interesse de Arantes. Um dos pioneiros da indústria da construção civil, ele foi agraciado com a Ordem do Mérito Industrial (2004), distinção concedida pela Federação das Indústrias do Estado de Santa Catarina. 


\section{UMANAS}

O seu nome e de outros que participaram da construção da Cidade Universitária foram mencionados em duas placas de bronze - uma delas desapareceu e a outra se encontra afixada na entrada do Centro de Comunicação e Expressão, a primeira edificação e funcionava a antiga Faculdade de Filosofia, Ciências e Letras.

RCH - Como v. tomou conhecimento do projeto de construção da Cidade Universitária?

Arantes - Após a minha formatura no curso de Engenharia, na Universidade Federal do Paraná (final de 1956), eu saí em busca de emprego. Eu entrei em contato com o engenheiro Otto Entres e imediatamente fui contratado. Eu gostei muito da cidade e Florianópolis estava crescendo, de modo que eu iniciei minhas atividades na Diretoria de Obras Públicas (DOP) em março do ano seguinte. Eu era engenheiro, mas logo assumi o cargo de Coordenador de Obras. É importante ressaltar que a idéia de construção da Cidade Universitária era antiga, os estudos preliminares já haviam sido realizados e algumas obras já estavam em andamento. Quem coordenava tudo isso era Henrique Fontes.

RCH - O local escolhido abrigava a Fazenda Modelo Assis Brasil, a qual foi transferida para a Ressacada, atrás do campo do Avaí. Como isso foi realizado? Arantes - O local pertencia ao Governo Estadual e foi cedido para a construção da Cidade Universitária; a fazenda tinha criação de gado, de cavalos e outros animais. Ela era bem cuidada e já existia algumas edificações, como moradias convencionais e até uma estrebaria. A própria transferência da fazenda foi algo complicado, pois o local na Ressacada teve que ser adaptado às novas funções e tivemos que realizar desapropriações de moradias, o que elevou consideravelmente os custos da operação, sem contar os cuidados necessários ao transporte dos itens (maquinários e animais). Apesar das dificuldades, a transferência ocorreu de modo satisfatório e todos os empregados colaboraram para o sucesso da mesma - parecia que existia uma energia positiva e que todos entendiam a importância do processo. $\mathrm{O}$ administrador da fazenda e seus auxiliares eram muito dedicados, pois o local estava bem cuidado e todos se envolveram nos trabalhos iniciais. Além das adaptações na Ressacada, o próprio local que abrigava a Fazenda Modelo Assis Brasil teve que ser adaptado para acomodar as unidades da futura universidade. Fontes elaborou o plano piloto, contratou arquitetos em São Paulo e o Governador Hülse apoiou integralmente o projeto.

RCH - Como era o seu relacionamento com o Desembargador Fontes? Arantes - Ele gostava de obras, era um homem meticuloso e acompanhava continuamente o desenvolvimento do projeto. Fonte visitava todos os dias os canteiros de obras, redigia relatórios e mantinha contato com os engenheiros e mestres-de-obras. Às vezes, ele se aproximava e me perguntava: 
Henrique da Silva Fontes e a criação da Universidade Federal de Santa Catarina

"Que horas v. vai para as obras?" Eu dizia: "às 7:00h". Ele pedia para que passasse em sua casa, para lhe dar carona; ele sempre foi pontualíssimo e, na hora marcada, ele já se encontrava no portão à minha espera - eu nunca esperei sequer $1 \mathrm{~min}$ para iniciarmos a viagem. Nos dois íamos de Jipe, as estradas eram terríveis e o percurso Centro-Trindade durava cerca de $35 \mathrm{~min}$. O carro ia pulando no caminho, mas o Desembargador agüentava tranquilamente as trepidações. Fontes também visitava regularmente o DOP, mantinha contato com Otto Entres e prestava contas diretamente ao Governador Hülse. Suas responsabilidades também exigiam viagens ocasionais ao Rio de Janeiro, para legalização da Faculdade Catarinense de Filosofia e obtenção de recursos para as obras. Ele viajava de ônibus e duravam mais de um dia, pois as estradas eram ruins e existiam as baldeações em Curitiba e São Paulo. Fontes já era um homem idoso e tinha muitas responsabilidades, de modo que certa ocasião eu lhe perguntei por que ele não aproveitava as comodidades de uma viagem de avião. Ele tinha pavor aos aviões e veio com a seguinte resposta: "Fique tranqüilo, Olavo, eu sempre viajo sentado!”.

RCH - A criação da Cidade Universitária foi algo extraordinário, mas alguns se manifestaram contrários à idéia, alegando dificuldades técnicas e custo elevado das obras. Qual é a sua opinião sobre o assunto?

Arantes - O local era amplo e exibia muita variabilidade na qualidade do solo e características topográficas. Quando realizamos uma obra do tamanho e da complexidade de uma Cidade Universitária, nem sempre conseguimos uma área $100 \%$ adequada aos nossos propósitos. As dificuldades topográficas e a umidade do solo exigiam um bom sistema de drenagem, mas tudo isso era previsível e nada tinha de excepcional. Os prédios foram construídos em locais adequados, de modo racional. Eles eram de dois pavimentos, tinham carga pequena e os estaqueamentos não ultrapassaram a $12 \mathrm{~m}$ de profundidade; isso era o máximo e nada tinha de excepcional. Alguns riachos foram canalizados, baixamos o nível do lençol freático com um eficiente sistema de drenagem e deixamos o terreno seco para as futuras construções. Tais providências facilitam a utilização de diferentes tipos de terrenos, embora as fundações dos prédios representem 5-6\% dos custos de uma obra - esses custos não pesam nos orçamentos e tampouco exigem técnicas sofisticadas de engenharia. As características da topografia e do solo nada tinham de especial que justificassem o abandono da Fazenda Modelo Assis Brasil; os bairros Trindade e Pantanal hoje contam com várias edificações com carga muito acima dos prédios de dois pavimentos que construímos na Cidade Universitária.

RCH - De acordo com o seu entendimento, a idéia de Fontes era a mais adequada para a época e as circunstâncias? 


\section{HUMANAS}

Arantes - As unidades que iriam compor a UFSC se encontravam espalhadas no centro de Florianópolis, mas Fontes queria aglutiná-las na Cidade Universitária. Alguns professores dessas unidades não apoiavam a transferência, por motivos próprios. Eles ocupavam posição de destaque ou exerciam funções públicas, tinham boa formação e prestavam um serviço ao Governo Federal. Durante o dia, eles tinham seus empregos ou exerciam atividades nos tribunais; à noite, ministravam aulas. As atividades desempenhadas na Faculdade de Direito se situava num plano secundário, algo como um "bico". As maiores resistências para a construção da Cidade Universitária se encontravam nessa unidade; eles eram contrários ao projeto por simples conveniência. É preciso também relembrar que o sistema de transporte era precário e o bairro Trindade se encontrava distante do Centro. Por outro lado, Fontes era um homem de visão, estava muito à frente do tempo, e sabia a importância de seu projeto. Ele idealizou e lutou arduamente em defesa do projeto e o Governador Heriberto Hülse lhe deu apoio integral, de modo que suas idéias ganharam força e predominaram.

RCH - Por que ele não foi nomeado reitor?

Arantes - Fontes tinha plena consciência que não tinha condições para assumir novos encargos. Ele não foi nomeado o reitor por dois motivos: a idade avançada, pois ele já havia sido jubilado há muito tempo, e por seu intenso relacionamento com Heriberto Hülse, governador pertencente à UDN; com a saída deste, surge um governador do PSD, o mesmo partido político do Presidente JK. Eu imagino que o afastamento de Fontes se deu de modo espontâneo, pois o seu sonho era finalizar as obras da Cidade Universitária; ele conseguiu finalizar uma boa parte das obras e inaugurou a primeira unidade (Faculdade de Filosofia, Ciências e Letras). Fontes vislumbrou a verdadeira função de uma universidade e conseguiu antecipar as nossas necessidades. Ele foi um homem extraordinário e a importância de seus feitos não pode ser esquecida.

\section{Theresinha de Jesus da Luz Fontes}

Ela é natural de Florianópolis/SC, nasceu em 6 de Setembro de 1929. Ela cursou o primário e o ginasial no Colégio Coração de Jesus (1936-44), foi aluna da Academia de Comércio de Santa Catarina, onde se formou como contadora (1947); cursou também a Faculdade de Ciências Econômicas, diplomando-se em 1951; por fim, bacharelou-se (11 de Janeiro de 1958) e licenciou-se ( 8 de Setembro de 1961) em Letras Neolatinas, pertencendo às primeiras turmas da Faculdade Catarinense de Filosofia. Exerceu a profissão de contador, por quase trinta anos: inicialmente, na Legião Brasileira de Assistência (LBA), a convite da Sra. Maria Konder Bornhausen, presidente da Instituição, ingressando, 
Henrique da Silva Fontes e a criação da Universidade Federal de Santa Catarina

depois, no serviço público estadual de Santa Catarina, onde se aposentou em Setembro de 1959. Participou de cursos de férias em Montevidéu (Uruguai), promovidos pelo Instituto de Estudios Superiores e, em Santiago do Chile, na Escola Normal Superior José Abelardo Nuñes. Fez parte da diretoria do Esperantista Klubo de Florianópolis e da Aliança Francesa; do Departamento Feminino da União Democrática Nacional (UDN) e da Campanha da Mulher pela Democracia (CAMDE); do Conselho Regional de Economia - $7^{\text {a }}$ Região CORECON-SC; e da Associação Católica Catarinense das Obras de Proteção ao Jovem. Nessas instituições exerceu a função de secretária ou tesoureira. Dona Theresinha foi aluna da primeira turma do curso de Letras Neolatinas (1955), ocasião em que teve oportunidade de ser aluna de seu pai. Ela é a filha mais nova, membro do Instituto Histórico e Geográfico de Santa Catarina e é responsável pelo vasto acerto documental e bibliográfico do Desembargador Fontes.

RCH - Descreva as origens e os vínculos familiares do Desembargador Fontes. Theresinha - "Esta é a ditosa pátria minha amada". Com este verso dos Lusíadas, o Professor Henrique da Silva Fontes, meu Pai, saudava Itajaí, quando o avistava numa das voltas do Morro Cortado. Foi nessa cidade que ele nasceu (15 de Março de 1885), numa casa da Rua Pedro Ferreira, a primeira paralela ao Porto e que começa na pracinha da velha Matriz, onde foi batizado. O seu Pai, Manuel Antônio Fontes, nasceu em 1844, na Cidade da Horta, da Ilha do Faial, no Arquipélago dos Açores, vindo aos quinze anos para o Brasil em companhia de seus pais Antônio da Terra e Francisca do Rosário Fontes e de seus irmãos José, Maria e Ana.

Português de nascimento, brasileiro por naturalização e de coração.

Profissionalmente, era comerciante e industrial; politicamente, um ardoroso republicano e, moralmente, um cidadão digno e respeitado. Ele pertencia à Guarda Nacional, com o posto de Coronel, concedido pelo Marechal Deodoro, que the foi cassado, porque, insatisfeito com aqueles que dominavam o poder, alistou-se entre os dissidentes federalistas. Mais tarde, porém, o posto the foi restituído. Relativamente a essa restituição, Papai escreveu de São Leopoldo a seu Pai, numa carta datada de 30 de Novembro de 1906: "P.S. Papae, acceite os meus parabéns, por ter sido readmittido nas gloriosas fileiras da "briosa" guarda nacional com o posto de tenente-coronel commandante da cavallaria. $\mathrm{O}$ Floriano, quando souber da notícia, lá no outro mundo, há de se dar o cavaco..."

Papai não se manifestava contra o nome de Florianópolis ou pela mudança dele para Desterro, mas certo dia ele disse: "Desterro é triste, mas não tem sangue", referindo-se à Revolução Federalista (1894), quando o interventor federal, Coronel Antônio Moreira César, deu início a uma série de prísões políticas, culminando com o fuzilamento de dezenas de pessoas na ilha de Anhatomirim. 


\section{HUMANAS}

Minha avó, Dona Ana da Silva Fontes, era filha do mestre-de-barco José Inácio da Silva, paulista, e, pelo lado materno, de Ana Jacinta da Silva, descendente de antiga família local. Vovó nasceu no Estreito, então parte do Município de São José, no último dia do ano de 1859. Ela era uma senhora profundamente religiosa; a sua casa era quase uma extensão da Matriz, onde a Dona Aninha, como era conhecida, tinha um genuflexório exclusivo para participar das celebrações e das missas diárias.

Papai tinha sete irmãos, quatro mulheres e três homens: Maria Concórdia, Francisca de Assis, Erotides e Virgínia. As duas últimas eram professoras normalistas e lecionaram no Grupo Escolar Floriano Peixoto, em Itajaí. Os irmãos exerciam atividades variadas: Eurico era empresário e industrial, Tomás Adalberto fora Cônego Honorário do Cabido de Santa Catarina, Deputado Federal e ainda era o editor-proprietário da Revista de Cultura, no Rio de Janeiro; Emanuel era Bacharel em Direito e funcionário do Banco do Brasil.

RCH - Como era o relacionamento com os filhos?

Theresinha - Em 25 de Janeiro de 1912, em Florianópolis, ele se casou com Dona Clotilde Arminda Born da Luz, natural de Palhoça/SC, filha de Jacinto José da Luz e de Júlia Madalena Born da Luz. O casal teve treze filhos, dos quais nove se criaram: Paulo de Tarso, Manuel Antônio, José, Victor, David, Bernadette Maria, Jorge, Alba Maria e Theresinha de Jesus. Eles comemoraram com muita alegria as bodas de ouro e, graças a Deus, Bernadette e eu somos as remanescentes!

Papai era muito ouvido e respeitado pelos irmãos, por ser o mais velho, mas ele não adotou o regime na nossa casa. Todos os filhos tinham os mesmos direitos, deviam-se respeitar mutuamente, e quem mandava era o casal: o que um decidia era acatado pelo outro. Era à Mamãe, mais light nas suas decisões, a quem recorríamos em primeiro lugar, e ela dizia: "fala com o teu Pai". Quando chegávamos a ele, fazendo o mesmo pedido, respondia, "fala com a tua Mãe". Ela já deixou, dizíamos nós: “então pode”!

RCH - ... E o seu relacionamento com Fontes?

Theresinha - Sempre houve boa interação entre meus pais e todos os filhos. Meu pai dava plena liberdade aos filhos, mas nunca perdeu a ascendência sobre nós; os filhos o estimavam muito e o consultavam em momentos necessários. Numa de suas cartas, ele dizia: "Não quero intervir em tuas idéias políticas. Deves tê-las e defendê-las, mas dentro dos princípios, da justiça e da verdade. Abraços e a bênção de teu pai e amigo" - H. Fontes, Florianópolis, 17 de Novembro de 1932. Ele aconselhava e orientava sem impor o seu pensamento. Eu era a caçula da família e compartilhava algumas de suas preferências, de modo que eu e Papai interagíamos perfeitamente. 
Henrique da Silva Fontes e a criação da Universidade Federal de Santa Catarina

Eu gostava de assistir às conferências e palestras promovidas pelo Instituto Histórico e Geográfico de Santa Catarina, a que, hoje, pertenço. Eu fiz o Curso de Letras Neolatinas na Faculdade Catarinense de Filosofia e tive oportunidade de ser sua aluna na disciplina Língua Portuguesa. Como eu lhe disse anteriormente, Papai não tinha automóvel, de modo que eu atuava como sua motorista. Eu o levava de cá pra lá, pois ele gostava dos passeios e levava os convidados para conhecerem a Faculdade de Filosofia ou às obras da Cidade Universitária.

Papai foi presidente do Instituto Histórico e Geográfico por 30 anos, instituição que era o grande promotor da cultura em Santa Catarina. Ele também foi membro da Academia Catarinense de Letras, a qual permaneceu por muitos anos como a "Bela Adormecida" e que hoje desempenha um papel importante para o desenvolvimento cultural do nosso estado. A Faculdade Catarinense de Filosofia também foi importante e cumpre notar que meu pai teve atuação de destaque nas três instituições.

RCH - Fontes teve uma produção intelectual ampla e variada. Descreva a sua formação acadêmica e trajetória profissional.

Theresinha - Meu pai participava intensamente da vida social de Itajaí; com apenas doze anos, assinou a Ata de criação da Sociedade Carnavalesca "Guarani". Ele realizou os primeiros estudos na terra natal, mas, em 1903, ele a deixa para ingressar no Ginásio Nossa Senhora da Conceição (São Leopoldo/RS).

Ele permaneceu em São Leopoldo por quatro anos, recebendo em dezembro de 1906, o grau de Bacharel em Ciências e Letras, tendo sido o orador da Turma. Ele foi aluno bem comportado e muito estudioso durante o curso Ginasial, pois recebeu cartões pela "Excelente conduta e aplicação" (NOTA DE HONRA) e obtenção mensal do primeiro lugar em diferentes matérias. O histórico escolar revela que meu pai era bom em Religião, Lógica, Astronomia, Português, Literatura, Latim, Grego, Alemão, Francês, Inglês, História Universal, História do Brasil, Corografia, Geometria, Física, Química e História Natural. Em São Leopoldo, além de aluno, ele também dava aulas particulares: aí começa a sua atuação como professor.

Do Rio Grande do Sul foi para o Rio de Janeiro, em 1907. As razões ele mesmo explica: "Era propósito meu formar-me em engenharia". As notas autobiográficas indicam que ele se matriculou na Escola Politécnica (1908) para atingir seus objetivos. Meu pai era um engenheiro em potencial, genuína vocação. Quando tinha condições financeiras, ele fazia reformas, ampliações e outros melhoramentos na casa, mudando paredes e abrindo portas. Como escreve: "Consegui matricular-me na Escola Politécnica, do Rio de Janeiro, em 1908; mas, por cansaço, interrompi os estudos, diplomando-me, afinal, quase vinte anos depois em direito". No Rio, se mantinha dando aulas particulares, daí, naturalmente, o seu desgaste físico e mental. 


\section{HUMANAS}

A partir de 1910, meu pai fixa residência em Florianópolis. Ele foi professor de Português e História do Brasil no então Ginásio Catarinense (1910-17); um curso comercial foi ali instituído, e ele passou a ensinar Escrituração Mercantil. Na estão Escola Normal Catarinense, Papai ministrou aulas de Pedagogia e Psicologia (1911-18) e, através de concurso, ele passou a ensinar História e Geografia. Ao chegar à Capital, ele fundou o semanário $A$ Época, de orientação católica. O primeiro número saiu a 16 de Outubro de 1910 e ele foi diretorproprietário até fins de Abril de 1911.

Em 1927, bacharelou-se na Faculdade de Direito do Paraná, tendo prestado os exames em segunda época. Nesse interregno, foi Encarregado do Serviço de Recenseamento Estadual (1918), Diretor da Instrução Pública (1919-26) e Secretário da Fazenda, Viação, Obras Públicas e Agricultura no Governo Adolfo Konder (1926-29). Depois de diplomado em Direito, meu pai exerceu os cargos de Juiz Federal Substituto (1929-34), Juiz do Tribunal Regional Eleitoral e Procurador do mesmo Tribunal (1932-34), Procurador Geral do Estado (193437) e Desembargador do Tribunal de Justiça de Santa Catarina (1937-46), cargo em que se aposentou.

O seu envolvimento com o ensino superior teve início simultâneo ou concomitante, pois ele se torna professor de Economia Política na Faculdade de Direito de Santa Catarina (1932-57), colaborando com o Desembargador José Arthur Boiteux na fundação desta instituição. Por isso, eu digo que meu pai é o operário da primeira hora da obra da Universidade de Santa Catarina e nela trabalhou até a sua conclusão. Ele começou a trabalhar em 1932, ao lado de José Boiteux, o "Patriarca do ensino superior em Santa Catarina", e foi até 15 de Setembro de 1961, quando a Faculdade de Filosofia foi incorporada nessa Universidade.

Ele foi Diretor da Faculdade de Direito por duas vezes (1933-35 e de 1942-45); na primeira gestão, ele instalou a faculdade num prédio próprio. Com a colaboração de outros professores, ele foi o fundador da Faculdade Catarinense de Filosofia, tendo sido o seu diretor desde a sua fundação ( 8 de Setembro de 1951) até ser incorporada pela Universidade Federal de Santa Catarina. Ele inaugurou a Cidade Universitária, pois instalou a Faculdade de Filosofia no primeiro prédio e a deixou em pleno funcionamento. Ele idealizou e participou intensamente da criação da UFSC, pois, de 1955 a 1961, ele foi "Encarregado dos estudos da criação da Universidade de Santa Catarina" (Lei estadual 1.362, 29 de Outubro de 1955), sem receber nenhuma remuneração pelos serviços. Deve-se acentuar que Papai, além do seu lado intelectual, era um homem de ação. Ele acompanhou a construção da Cidade Universitária e vistoriava diariamente o andamento das obras; ele também se dirigia à Diretoria de Obras Públicas do Estado para saber detalhes da execução dos serviços.

Também merecem menção as funções de cunho cultural e social que exerceu: Presidente do Instituto Histórico e Geográfico de Santa Catarina (1935-65), 


\section{Henrique da Silva Fontes e a criação da Universidade Federal de Santa Catarina}

Provedor da Irmandade do Divino Espírito Santo e Asilo de Órfãs São Vicente de Paulo (1929-32), sendo em sua gestão ampliado o prédio e construída a capela, e o primeiro Diretor-Geral da Casa dos Professores de Santa Catarina (1952-57), tomando parte na organização do seu Estatuto e deixando-a instalada em prédio próprio.

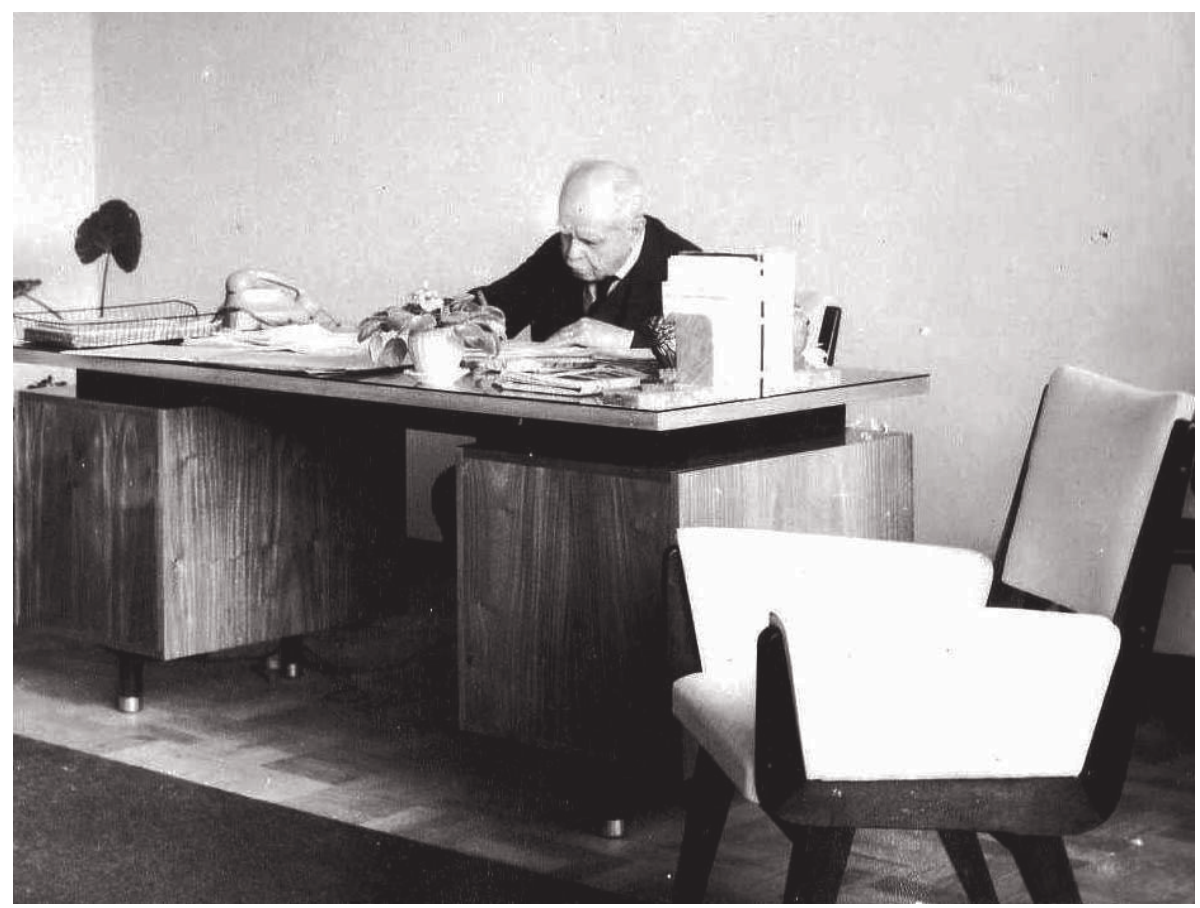

Figura 6

O desembargador em seu gabinete de trabalho (Faculdade de Filosofia, Ciências e Letras, Cidade Universitária, início de 1960).

RCH - ... E suas leituras preferidas? Assuntos prediletos?

Theresinha - As leituras eram variadas e meu pai gostava dos livros. Eu acho interessante citar um trecho da carta que Altino Flores enviou à Carlos da Costa Pereira, por ocasião do falecimento de meu pai: "Fontes, a meu ver, era o catarinense mais ilustre (quero dizer: ilustrado) que já teve a nossa terra... Ilustrado, sim, era ele por ser culto, no mais belo sentido da palavra..." A diversidade de conteúdo dos livros e de línguas - hebreu, grego, alemão, latim, português, francês, espanhol e outras - que compunham a sua biblioteca, evidenciam uma leitura bastante eclética. Os estudos antroponímicos o levavam a manusear livros bíblicos, obras clássicas da mitologia, dicionários etimológicos e tantos outros, para a interpretação dos nomes próprios. 


\section{HUMANAS}

Como juiz, desembargador, professor de Economia Política na Faculdade de Direito e de Língua Portuguesa na Faculdade de Filosofia, eram os livros de natureza jurídica, econômica, gramáticas históricas e expositivas, autores clássicos e modernos que mereciam a sua atenção. Papai focava as suas leituras conforme as circunstâncias e necessidades e, com efeito, às vezes dizia: "os livros que compro, leio quando posso; mas os livros que me dão, imediatamente os leio para agradecer o presente". A sua biblioteca não parava de crescer!

RCH - Quais são suas lembranças acerca de seu pai? Como os filhos interagiam com ele?

Theresinha - São as melhores lembranças que guardo de meu pai, somadas às lembranças que também tenho de minha Mãe. Sempre que se fala nele, vem à minha memória a figura de Mamãe: uma mulher calma, boa, compreensiva, religiosa, caridosa, mãe dedicada e perfeita dona de casa. Recebia muito bem os parentes, os amigos do marido e dos filhos. Meu pai era uma fonte permanente de consultas: sempre que surgia alguma dúvida, os filhos a ele recorriam - se fosse alguma coisa de Português, ele nos mandava ao Aulete, e se fossem coisas jurídicas, recomendava uma consulta à Constituição ou ao Código Civil. Ele não dava colher de chá! Depois, então, se discutia...

Ele tratava os filhos da mesma maneira, diferindo apenas na educação dos rapazes e das moças. Por exemplo: eles freqüentavam a escola pública (Grupo Escolar Silveira de Sousa) e nós, o Colégio Coração de Jesus. Outra coisa que lembro bem eram seus passeios pela cidade. Há muito tempo atrás, o meio de transporte era o bondinho de burro, o carrinho de cavalo ou ônibus. Papai nunca teve automóvel, mas nós tínhamos e o levávamos para onde nos pedisse. Ele gostava desses passeios, principalmente aos domingos. Quando um de nós lhe perguntava o destino, ele respondia: primeiro a Cidade Universitária, depois onde quiserem.

RCH - Os amigos relembram o idealismo e a capacidade aglutinadora de Fontes, mas não mencionam seus traços de personalidade. Fale um pouco sobre o assunto.

Theresinha - Papai tinha uma personalidade marcante e mantinha sempre o mesmo humor - não era bipolar, como se fala hoje. Era muito sisudo e essa aparência deixava meio assustado a quem pela primeira vez o procurasse. Mas era só a aparência: ele era um homem muito bom, sincero e justo. Como disse Oswaldo Cabral, à beira do seu túmulo: "Sob a face de uma austeridade que apenas servia para mal encobrir a enormidade do teu coração e da tua bondade - fostes o amigo e conselheiro de todas as horas, desprendido de vis interesses e de mesquinhas ambições". Ele atendia corretamente a todos, tanto o pobre, que batia à sua porta, pedindo um auxílio ou um prato de comida, 


\section{Henrique da Silva Fontes e a criação da Universidade Federal de Santa Catarina}

como o rico que o visitava freqüentemente. O mesmo tratamento ele dispensava aos subordinados, alunos, professores e colegas de trabalho. A sua conduta era guiada pelo senso de justiça, começando dentro de sua família e terminando no relacionamento com outras pessoas.

Meu pai tinha as feições e o jeito de uma pessoa séria, mas tinha bom humor e gostava das reuniões de confraternização. Ele apoiava as festas juninas promovidas pelos Centros Acadêmicos: na primeira (Faculdade de Direito), o santo homenageado era São João e, na segunda (Faculdade Catarinense de Filosofia), era Santo Antônio, o santo casamenteiro (a maioria era feminina); o dia de São Pedro e São Paulo (29 de Junho) já estava reservado para a fogueira em nossa casa. É uma festa ainda mantida por nossa família, a qual começou em Itajaí nos idos de 1880, na casa de meus avós paternos. Na Faculdade de Filosofia, tudo era motivo para festa; além da fogueira, havia feijoada, bacalhoada e coquetéis. Com os seus próprios recursos, o Papai mandou fazer um galpão na área externa da Faculdade para os alunos se reunirem, chovesse ou fizesse sol.

Outra característica que deve ser levada em conta para se compreender a personalidade de meu pai é a sua religiosidade. Ele tinha muita fé em Deus, era católico convicto! Ele pertencia à Irmandade do Senhor dos Passos e à do Santíssimo Sacramento, na Catedral - muitas vezes ele carregou a vara do pálio nas procissões. Quando o seu féretro passou pela Igreja de Nossa Senhora de Lourdes e São Luís, no bairro da Agronômica, os sinos tocaram em tom fúnebre, homenageando o fiel paroquiano. $\mathrm{O}$ seu falecimento ocorreu a $22 \mathrm{de}$ Março de 1966, no Hospital de Caridade, e foi velado em sua residência, à Avenida Trompowsky, número 14. No dia seguinte, o seu corpo foi sepultado no Cemitério São Francisco de Assis, em Florianópolis; houve grande acompanhamento, muitas flores e discursos de despedida. Mamãe faleceu seis meses antes, a 15 de setembro de 1965 .

RCH - Seu pai foi um construtor de instituições, mas não podemos esquecer o legado intelectual. Descreva suas obras e seus interesses acadêmicos.

Theresinha - Eu poderia citar alguns livros, discursos e conferências proferidas por meu pai. Ele também publicou uma série de livros de ensino elementar, a qual fora iniciada quando ele era Diretor da Instrução Pública (1920). A Série Fontes era composta por uma cartilha e quatro livros de leitura, publicados sem reserva de direitos autorais, o que significa que não trazia nenhuma vantagem econômica ao meu pai; a Série Fontes até hoje serve de tema para teses e dissertações nos cursos de pós-graduação. Outras contribuições que merecem destaque são: O Conselheiro José Mascarenhas Pacheco Pereira Coelho de Melo (biografia, 1938), Lacerda Coutinho (biografia e crítica literária, 1943), A Beata Joana Gomes de Gusmão (biografia, 1954), O Irmão Joaquim, 


\section{HUMANAS}

o Vicente de Paulo Brasileiro (biografia, 1958), Digressões Antroponímicas (filologia, 1951), A Faculdade de Direito de Santa Catarina e seus primeiros tempos (conferência, 1957), Nomes germânicos de mulheres (filologia 1959), O nosso Cruz e Sousa (discurso, 1961) e Pensamentos, palavras e obras (discursos e noticiário). A sua última contribuição intelectual foi o livro $A$ Irmandade do Senhor dos Passos e o seu Hospital e aqueles que os fundaram (história, 1966). A obra foi iniciada em 14 de Janeiro de 1964 (Veni, Creator Spiritus!) e finalizado em 6 de agosto de 1965 (Deo gratias!). Em 19 de Fevereiro de 1966 eu fui com Papai ao Hospital de Caridade para oferecer o primeiro exemplar ao Desembargador João da Silva Medeiros Filho, Provedor da Irmandade do Senhor dos Passos. O livro foi escrito em comemoração aos 200 anos da Irmandade; ele doou 700 exemplares, para que os lucros da vendagem fossem em benefício das obras sociais. Ele deixou em adiantada elaboração um Dicionário etimológico e comparativo de nomes pessoais, proferiu muitos discursos no exercício de suas funções públicas ou como paraninfo de formandos; eu cito também os incontáveis artigos publicados nos jornais, sobre variados (biografias, história, teses econômicas e filologia).

RCH - Como era a sua rotina de trabalho? Manias e idiossincrasias?...

Theresinha - Eu sou a filha mais moça, a mais nova da família; em relação ao meu irmão Paulo, o mais velho, havia uma diferença de quinze anos. Eu pouco sei dos primeiros tempos da família e, portanto, as minhas lembranças se referem à década de 1940 em diante, quando já tinha os meus onze anos. Eu sempre via Papai lendo ou escrevendo, mas a hora das refeições era sagrada e controlada pelo relógio. Quem chegasse atrasado que comesse frio - não existia forno de micro-ondas! Ele gostava de comer bem e todos os pratos the agradavam; apreciava uma mesa farta e até dizíamos: "Papai só não come jiló!" Papai gostava de receber os amigos em casa e de oferecer um almoço ou jantar aos amigos "de fora". Todos os aniversários da família eram comemorados; tínhamos o respaldo da Mamãe, que era boa cozinheira e doceira. As conversas com a família se realizavam após as refeições.

Era pontual em todos os seus compromissos: missa dominical, aulas, sessões, reuniões, encontros sociais e culturais. Ele não costumava trabalhar à noite, pois considerava que as horas noturnas eram para o descanso, mas saía quando tinha algum compromisso ou por imposição das aulas. Durante muitos anos, as quintas-feiras eram reservadas para as sessões do Instituto Histórico, que começavam às vinte horas. Nessas ocasiões, Dr. Oswaldo Cabral o pegava de carro e o trazia de volta do compromisso. Papai tinha medo de trovoada e não gostava das alturas; as suas viagens eram por terra ou por mar. Entretanto, o temor aos aviões não atrapalhou as suas atividades em outros estados, como demonstram as incontáveis viagens ao Rio de Janeiro para tratar dos interesses das Faculdades de Direito (1937) e de Filosofia (década de 1950). 


\section{Henrique da Silva Fontes e a criação da Universidade Federal de Santa Catarina}

Não me lembro de alguma mania, exceto o fato que ele não gostava de ouvir porta batendo ao vento ou torneira pingando. Ele não era uma pessoa neurastênica, no sentido popular ou como define o Aurélio: "indivíduo mal-humorado e irascível". Ele não se incomodava com o barulho dos netos, com o telefone chamando ou com quem batesse à porta. Quantas vezes, ele mesmo, deixando o seu trabalho, atendia os meninos que surgiam pedindo jornais para vender! Durante muitos anos, Papai manteve um hobby: a arte fotográfica. Ele mesmo fotografava, revelava, ampliava e até coloria. Tinha em casa um pequeno laboratório e despendia algum tempo nessas atividades. Por outro lado, se comprar livros pode ser classificado como uma mania, podemos dizer que Papai a tinha! Ele estava sempre ampliando a biblioteca, como dizia Mamãe: "pra livros tu sempre tens dinheiro!"

Meu pai tinha o seu gabinete de trabalho, junto à biblioteca, mas, dependendo do que estava escrevendo e de acordo com suas necessidades, ele ocupava a copa ou sala de jantar; os livros "decoravam" os móveis e os compartimentos da casa. Dr. Roberto Macedo, advogado no Rio de Janeiro, visitou a nossa casa e publicou suas impressões acerca do modo como meu pai trabalhava: "Na biblioteca particular, cientificamente desorganizada, comendo pé de moleque, lê grego no original, perante amigos que pedem tradução". Detalhe importante: a visita ocorreu no dia da fogueira de São Pedro (Correio da Manhã, Rio de Janeiro, 15 de Janeiro de 1950). Dr. Roberto tinha razão sobre a "desorganização científica" da biblioteca, pois Papai sabia onde estavam os livros, as revistas, as cartas, os documentos e seus papéis. Ele sabia a exata localização do material e nós não podíamos tirar nada de seu lugar! Nos últimos anos, quando estava escrevendo o livro "A Irmandade do Senhor dos Passos" (1966), ao iniciar o dia de trabalho, no jardim de inverno da casa, escrevia a caneta numa mesinha com tampo de vidro Veni Creator Spiritus; finalizava o dia com Deo gratias!, sempre apondo as datas em seus escritos.

RCH - No contexto nacional e catarinense, qual é o significado de sua obra? Theresinha - A projeção intelectual no cenário brasileiro foi alcançada com a publicação de livros e outras contribuições (artigos de jornais, discursos e conferências). Papai não vendia os livros, oferecia aos amigos. Ele é citado por autores catarinenses e de outros estados; as cartas que ele recebeu agradecem o envio dos livros, ao mesmo tempo em que enaltecem o modo como os assuntos foram abordados. A sua correspondência testemunha o relacionamento com intelectuais, filólogos e historiadores de renome nacional. Ele foi representante do Estado de Santa Catarina na Conferência Interestadual de Ensino Primário (1921, no Rio de Janeiro), ocasião em que interagiu com especialistas de várias instituições e, conseqüentemente, se tornou conhecido entre os intelectuais do Brasil e exterior. 


\section{HUMANAS}

Outro evento de grande significado foi o I Congresso de História Catarinense (1948), em comemoração ao Segundo Centenário da Colonização Açoriana. Historiadores gaúchos, paranaenses, paulistas e cariocas participaram do congresso, além de Manuel de Paiva Boléo (1904-92), conhecido intelectual português. O congresso projetou Santa Catarina além das fronteiras nacionais e foi organizado pelo Instituto Histórico e Geográfico de Santa Catarina - o evento ocorreu durante a sua presidência e coube a meu pai presidi-lo. Meu pai apresentou comunicação em outros eventos, entre as quais: "Uma gramática baseada na Réplica de Ruy Barbosa" (1949, Rio de Janeiro), "Importância dos nomes de pessoas para estudos de psicologia social" (1953, Curitiba), "A Beata Joana Gomes de Gusmão" e "O empréstimo a juros desde as Ordenações do Reino até a atual legislação brasileira" (1954, São Paulo).

RCH - Como Fontes se relacionava com a intelectualidade catarinense?

Theresinha - O seu relacionamento com os intelectuais catarinenses era muito bom e amistoso, tanto com os "velhos", quanto com os "novos" - estou me referindo ao pessoal de sua geração e aos jovens que integravam o grupo Sul e o Museu de Arte Moderna. O escritor Salim Miguel publicou o artigo "Lembranças do Professor" ("O Estado") e seus comentários esclarecem o modo como meu pai se relacionava com os jovens: "... podia discordar da irreverência dos jovens, mas lia e assistia os seus trabalhos, e comparecia às tumultuadas palestras... Nós o admirávamos por sua retidão, suas posições conservadoras mas francas e honestas, sua cultura aberta..." Como podemos notar, os jovens intelectuais respeitavam meu pai, da mesma forma que ele os tinha em elevada estima. Assim sendo, eu acho apropriado citar alguns trechos de seu discurso proferido durante a presidência do Instituto Histórico e Geográfico de Santa Catarina, na sessão da reinstalação do Museu de Arte Moderna, em 1958: “... Nunca houve repugnância entre o velho Instituto, que parece voltado tão somente para o pretérito, e o novel Museu, que parece voltado só para o presente. É que nenhuma das duas instituições se mumifica dentro do respectivo espírito de 'histórico' e de 'moderno'. O Museu o está exemplificando nesta hora: pois não promove ele um curso e exposição da arte egípcia, e não do Egito vulcânico de hoje, mas do Egito hierático dos Faraós? E assim praza a Deus que o seja sempre, porque um museu como este, mesmo que se diga de 'arte moderna', não pode ficar parado e pasmado ante o atual, mas deve ser retrocessivo e expansivo, procurando a beleza onde ela esplender, porque a beleza, a verdadeira beleza, não deformada por estrabismos de escolas nem por delírios individuais, não tem data nem pátria, é sempre atual, é moderna perpetuamente".

Papai mantinha viva a sua formação clássica, mas não se opunha às inovações culturais. Ele também era apreciador das inovações tecnológicas - assim que surgiu a cibernética, comprou um livro para se inteirar da nova ciência. 


\section{Henrique da Silva Fontes e a criação da Universidade Federal de Santa Catarina}

Imaginemos Papai na era da informática! Teria produzido algumas vezes mais, se não fosse o tempo perdido em cortar com a tesoura e colar com gomaarábica as folhas do texto que escrevia a mão e depois datilografava; o trabalho era cansativo e meticuloso, pois as tiras às vezes tinham mais de um metro!

RCH - Quais eram os seus amigos?

Theresinha - Não dá para enumerar todos os seus amigos, os quais foram conservados desde os tempos de São Leopoldo. A enorme quantidade de cartas expedidas (cópias) e recebidas estão nos arquivos; elas revelam quem eram seus amigos e o acervo até serviu como tema para dissertação de mestrado na UFSC. As cadernetas de endereços eram volumosas, pois eram continuamente atualizadas, e eram úteis para envio de correspondências, remessas de livros e cumprimentos de Natal e Ano Novo. Nas comemorações das bodas de ouro de Papai e Mamãe, que foi em nossa casa, tornou-se inviável expedir convites a todos os amigos, pois o número era enorme e corríamos o risco de causar melindres com as omissões. A solução foi convidarmos os parentes e amigos através dos jornais da Capital. E tivemos razão! Aproximadamente, quinhentas pessoas vieram abraçar o casal, desde a missa, que foi celebrada pela manhã em casa, porque Mamãe já estava doente e acamada, até o coquetel, à noite.

Eu acho inadequado citar quem eram os amigos de meu pai, pois eles eram numerosos e corremos o risco de perpetrar o mesmo tipo de injustiça! Interessantemente, a biblioteca de Papai tinha dois livros sobre a importância das amizades: "Como fazer amigos e influenciar pessoas" (How to win frien$d s$ and influence people, 1937), de Dale Carnegie, e uma paródia de seu livro, "Como perder amigos e aborrecer pessoas" (How to lose friends and alienate people, 1941), de Irving Tressler.

RCH - Fontes acolheu alguns intelectuais evadidos da ditadura salazarista, os quais contribuíram significativamente para o sucesso da Faculdade Catarinense de Filosofia. Descreva o seu relacionamento com esse pessoal.

Theresinha - Os professores portugueses George Agostinho Baptista da Silva e Eudoro de Sousa vieram para Santa Catarina, especialmente para lecionarem na Faculdade Catarinense de Filosofia. Os dois eram intelectuais de extraordinária cultura, foram perseguidos durante o regime da ditadura salazarista $\mathrm{e}$ atenderam ao convite de meu pai para colaborar com o ensino da Faculdade Catarinense de Filosofia. Meu pai tinha espírito democrático, não apoiava a ditadura e, assim, não havia nenhuma controvérsia política.

Professor Agostinho veio para lecionar Literatura Portuguesa e Filologia. Ele era um "Cidadão do mundo", tinha amplos conhecimentos e todas as perguntas feitas pelos alunos eram respondidas, dentro ou fora da aula. 


\section{HUMANAS}

Para falar na cultura do Professor Eudoro, que lecionava Língua e Literatura Grega e também História da Antiguidade, basta dizer que ele traduziu do original a Poética de Aristóteles. O relacionamento pessoal entre Papai e esses professores era muito bom; especialmente, com o Professor Eudoro e sua mulher Dona Maria Luísa, cantora de fados. O casal era assíduo freqüentador da nossa casa e das festas promovidas pela família. Existia um clima de fraternidade na convivência dos alunos e professores, o que era devido ao amor que meu pai tinha pela instituição e ao modo como tratava os problemas administrativos.

RCH - O que significou para o seu pai o sucesso do "projeto UFSC"? Quais foram suas dificuldades e seus êxitos?

Theresinha - A criação de uma universidade era um sonho que já vinha sendo acalentado desde 1937. Ele se tornou realidade com a Lei Federal 3.849 (18 de Dezembro de 1960), assinada pelo Presidente Juscelino Kubitschek e que deu vida à Universidade Federal de Santa Catarina. Além da universidade, meu pai tinha clara a intenção de criar uma Cidade Universitária para aglutinar as faculdades num só local. Tudo começou quando ele idealizou um "quarteirão universitário" nas imediações da Faculdade de Direito, na Rua Esteves Júnior, nesta Capital. Essa idéia de "quarteirão" agigantou-se e se transformou na Cidade Universitária de Santa Catarina, atualmente "Campus Universitário". Não foi nada fácil a implantação do complexo universitário, em razão da oposição acirrada de um grupo de professores que queria localizá-lo na Rua Bocaiúva, no centro da Cidade. Entretanto, meu pai tinha o apoio de grande parte dos professores e dos estudantes secundaristas e universitários, os quais manifestaram o apoio através de suas entidades. Era uma idéia justa e racional, conforme ficou comprovado ao longo do tempo - ele lutou por suas idéias e venceu!

Meu pai enfrentou muitas dificuldades para realizar seus objetivos universitários, desde os tempos na Faculdade de Direito, os quais o levaram duas vezes ao Rio de Janeiro (1937) para tratar do seu reconhecimento. Ele conseguiu. A morte do idealista José Arthur Boiteux, em 1934, dois anos após a fundação dessa Faculdade, aumentou a responsabilidade dos seus seguidores para também não morrer o seu ideal. "Agonizantinha", usando uma expressão do Papai, ela esteve; mas sobreviveu! Depois, veio a Faculdade de Filosofia, peça fundamental para a criação da tão sonhada Universidade de Santa Catarina que lhe deu muito trabalho. Criada em 1951, só começou a funcionar em 1955. Nesse período Papai foi seis vezes ao Rio de Janeiro, passando por São Paulo, para resolver as diligências e pendências no Ministério da Educação e contratar professores para as disciplinas dos Cursos de Letras Neolatinas, Anglogermânicas e Clássicas, História e Geografia e do Curso de Didática. Ele viajava de navio, de ônibus e de trem para chegar à Capital Federal. Eram viagens longas e o seu tempo de permanência, principalmente no Rio, também era longo. 


\section{Henrique da Silva Fontes e a criação da Universidade Federal de Santa Catarina}

Mas as dificuldades foram compensadas, pois ele conseguiu instalar a Faculdade Catarinense de Filosofia e contratar professores de renome para ministrar as aulas.

RCH - Dê o seu depoimento pessoal sobre o esquecimento de sua obra.

Theresinha - Não me parece justo esquecer a sua participação na criação da Universidade Federal de Santa Catarina. Ele começou em 1932 com José Artur Boiteux, na criação da Faculdade de Direito, a pedra fundamental do ensino universitário catarinense. Mais injusto ainda é dizer que "Henrique Fontes era contra. Ele atrapalhou um pouco a nossa luta", como falou o Reitor João David Ferreira Lima numa entrevista concedida ao jornalista Apolinário Ternes. O jornalista perguntou acerca das pessoas que contribuíram para o sucesso do empreendimento, os pioneiros e qual foi a contribuição de meu pai. Ferreira Lima respondeu de modo injusto e inadequado: "Henrique Fontes era contra. Ele atrapalhou um pouco a nossa luta. Ele era contra, né, porque queria uma universidade estadual, e nós lutávamos por uma federal. Ele queria uma estadual, ou particular. Mas tínhamos muitos companheiros. Os colegas foram muitos nessa luta" (A Notícia, Joinville/SC, 24 de Junho de 1996).

Papai não era contra a Universidade Federal: dentro das suas atribuições de "Encarregado dos estudos da criação da Universidade de Santa Catarina", ele encaminhava o processo pelo regime de instituto livre, como eram constituídas as faculdades em Santa Catarina. Assim, ele esclarece: "No tocante à organização jurídica da Universidade, em razão de serem particulares as Faculdades que poderiam integrá-la, projetou o Estado a sua criação como instituto livre, dando-lhe para entidade mantenedora uma fundação com recursos para custear os órgãos universitários, auxiliar o ensino superior e dar andamento à Cidade Universitária".

Ele trabalhou intensamente no cumprimento da missão que lhe foi confiada - uma universidade para Santa Catarina. Ser "contra" é uma coisa bem diferente! Se meu pai fosse contra ao projeto, ele não teria assinado, na qualidade de Diretor da Faculdade Catarinense de Filosofia, depois de incluída a Cidade Universitária, a Representação que foi entregue ao Presidente da República, pelo Governador Heriberto Hülse, solicitando a criação de uma universidade federal em Santa Catarina. Muito menos se teria dirigido ao Governador Heriberto Hülse, bem antes da entrega da Representação acima citada, que ocorreu no segundo semestre do mesmo ano, nestes termos:

Caso, porém, ache Vossa Excelência ser mais conveniente promover entendimento com o Senhor Presidente da República para que a Universidade de Santa Catarina seja do padrão das que o Governo Federal mantém em grande número de Estados, 


\section{HUMMANAS}

parece-me também, e peço vênia para o dizer, que Vossa Excelência pode tomar essa iniciativa sem o menor constrangimento, visto como não se apresentará como simples pedinte, pois que o Estado doará à União ampla e bela Cidade Universitária, bem traçada e já iniciada, e os professores catarinenses, que fundaram Faculdades livres, que o Estado vem ajudando, as apresentarão em condições de serem federalizadas, como já o foi, e com justiça, a Faculdade de Direito. Outra ou outras soluções mais lúcidas e práticas poderão ocorrer a Vossa Excelência e as estudarei, se Vossa Excelência assim o desejar. Seja como for, manifesto a minha certeza, Senhor Governador, de que Vossa Excelência, animado pelo êxito da sua ação pessoal na instalação da Faculdade de Medicina, ultimará providências para que, ainda em seu governo, surja a Universidade de Santa Catarina (Oficio de 20 de Fevereiro de 1960).

Diante de tudo isso, eu pergunto: Com toda essa franqueza e abertura, Papai era contra a Universidade Federal? Se ele não acompanhou o Governador Heriberto Hülse, quando esse viajou a Brasília, para solicitar do Presidente Juscelino Kubitschek a criação da Universidade Federal, é porque não foi convidado.

A comitiva que acompanhou o governador era composta pelos diretores das faculdades, a saber: João David Ferreira Lima (Faculdade de Direito), Roldão Consoni (Faculdade de Medicina), Luiz Oswaldo d'Acampora (Faculdade de Farmácia) e Nicolau Severiano de Oliveira (Faculdade de Ciências Econômicas). Meu pai era o "Encarregado dos estudos da criação da Universidade de Santa Catarina", cargo de confiança do Governador do Estado, nãoremunerado, mas não foi incluído na comitiva. Foi mais uma injustiça perpetrada contra meu pai!

$\mathrm{Na}$ verdade, para a criação da Universidade, quer pelo regime federal, quer pelo regime de instituto livre, a matéria prima a ser apresentada era a mesma que, há vinte e oito anos, vinha sendo plasmada pelos professores catarinenses: as faculdades existentes em Santa Catarina, as quais não nasceram por encanto ou por meio de uma varinha de condão. Elas são frutos de uma persistente e sistemática luta em prol do ensino superior. Desse modo, é inapropriado dissociar a Universidade Federal de Santa Catarina desses institutos livres, a começar pela Faculdade de Direito (a primeira a ser federalizada); o que houve foi a federalização dos demais institutos, fato que não pode ser escondido nem esquecido. 


\section{Henrique da Silva Fontes e a criação da Universidade Federal de Santa Catarina}

Essas pessoas conseguiram excluir Henrique da Silva Fontes, meu pai, dos trâmites finais da criação da Universidade Federal de Santa Catarina; mas não conseguiram excluí-lo de sua história. Os documentos e suas obras comprovam que ele contribuiu decisivamente para a realização desse sonho; seus esforços datam de 1932, quando, ao lado de José Arthur Boiteux, ele trabalhou arduamente para fundar a Faculdade de Direito de Santa Catarina. 